Andrews University

Digital Commons @ Andrews University

2016

\title{
A Strategy for Planting Missional Churches to Include and Disciple the Postmodern People in the South of Brazil
}

Natal Gardino

Andrews University

Follow this and additional works at: https://digitalcommons.andrews.edu/dmin

Part of the Practical Theology Commons

\section{Recommended Citation}

Gardino, Natal, "A Strategy for Planting Missional Churches to Include and Disciple the Postmodern People in the South of Brazil" (2016). Professional Dissertations DMin. 500.

https://dx.doi.org/10.32597/dmin/500

https://digitalcommons.andrews.edu/dmin/500

This Project Report is brought to you for free and open access by the Graduate Research at Digital Commons @ Andrews University. It has been accepted for inclusion in Professional Dissertations DMin by an authorized administrator of Digital Commons @ Andrews University. For more information, please contact repository@andrews.edu. 


\begin{abstract}

\section{A STRATEGY FOR PLANTING MISSIONAL CHURCHES TO INCLUDE AND DISCIPLE THE POSTMODERN}

PEOPLE IN THE SOUTH OF BRAZIL
\end{abstract}

by

Natal Gardino

Adviser: Russell Burrill 


\author{
ABSTRACT OF GRADUATE STUDENT RESEARCH \\ Project Document \\ Andrews University \\ Seventh-day Adventist Theological Seminary
}

Title: A STRATEGY FOR PLANTING MISSIONAL CHURCHES TO INCLUDE
AND DISCIPLE THE POSTMODERN PEOPLE IN THE SOUTH OF BRAZIL

Name of Researcher: Natal Gardino

Name and degree of faculty adviser: Russell Burrill, DMin

Date Completed: November 2016

\title{
Problem
}

In spite of the fact that the Seventh-day Adventist Church is growing in Brazil, the traditional evangelistic methods have not significantly reached people with a postmodern worldview, who (in this country) are generally younger, wealthier, and more educated. This present study was to mobilize the churches in the South of Brazil with information and strategies to include postmodern people in their evangelistic efforts both in the local church and in new planted churches as well. 


\section{Method}

Curitiba Central Church was informed about the reality of the contemporaneous worldview, and leaders of the church and volunteers were trained, making the members and leaders of church departments more concerned about adapting their language and approach as much as possible within the limits of a traditional church, to reach

postmoderns. Then a plan was made to plant a new church from within Curitiba Central, which would be focused specifically on including postmodern people, who are very unlikely to attend a conventional church at first.

The new church plant was open every day and featured different events for the good of the community. The worship services had their place every Saturday morning, as well as Sundays and Wednesdays at night, and they consisted basically of three or four worship songs, prayer and the presentation of the Bible principles for the everyday life. Two different Bible classes were always available during the week for those who wanted more information.

\section{Results}

At the end of two years, the new church plant, which began with 39 trained members from the Curitiba Central Church and volunteers from other churches as well, baptized 26 people and counted 134 members. Though these numbers may not be much impressive in Brazil, the profile of the people baptized certainly is for being in the difficulty range of postmodern-prone people in Brazil: young adults and formally educated people.

When considering the proportions, the new church plant has much more members in this category than any other church in the local Union Conference (although less than 
churches on university campuses). And these members are constantly trained to keep this configuration increasing by always inviting their friends and colleagues to the church community.

\section{Conclusions}

Church members in Brazil must learn about the reality of the postmodern reality and learn how to include people with this worldview in their evangelistic efforts. The local church can be adapted as much as possible in order to make their programs more interesting through the use of clear language, relevant lectures, more interaction with people, and the creation of different new ministries to involve every member in active services to the community. Planting new churches is also very important to reach and include people who would normally never attend a traditional church. 
Andrews University

Seventh-day Adventist Theological Seminary

\title{
A STRATEGY FOR PLANTING MISSIONAL CHURCHES TO INCLUDE AND DISCIPLE THE POSTMODERN \\ PEOPLE IN THE SOUTH OF BRAZIL
}

\author{
A Project Document \\ Presented in Partial Fulfillment \\ of the Requirements for the Degree \\ Doctor of Ministry
}

by

Natal Gardino

November 2016 
(c) Copyright by Natal Gardino 2016 All Rights Reserved 


\title{
A STRATEGY FOR PLANTING MISSIONAL CHURCHES \\ TO INCLUDE AND DISCIPLE THE POSTMODERN \\ PEOPLE IN THE SOUTH OF BRAZIL
}

\author{
A project document \\ presented in partial fulfillment \\ of the requirements for the degree \\ Doctor of Ministry
}

by

Natal Gardino

APPROVAL BY THE COMMITTEE:

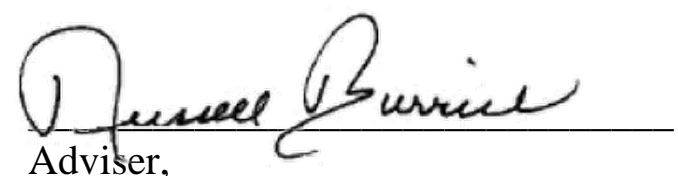

Russell Burrill
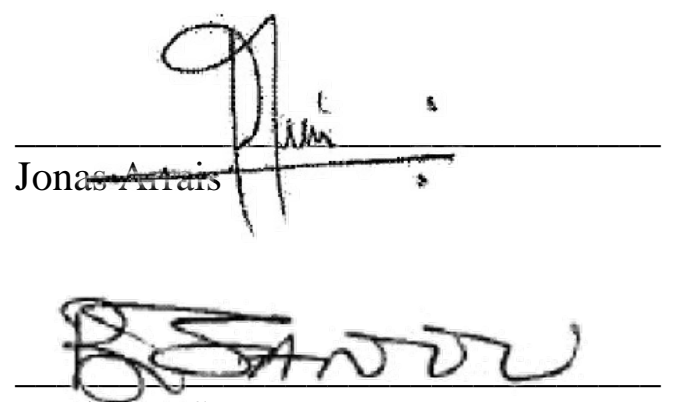

Boubakar Sanou

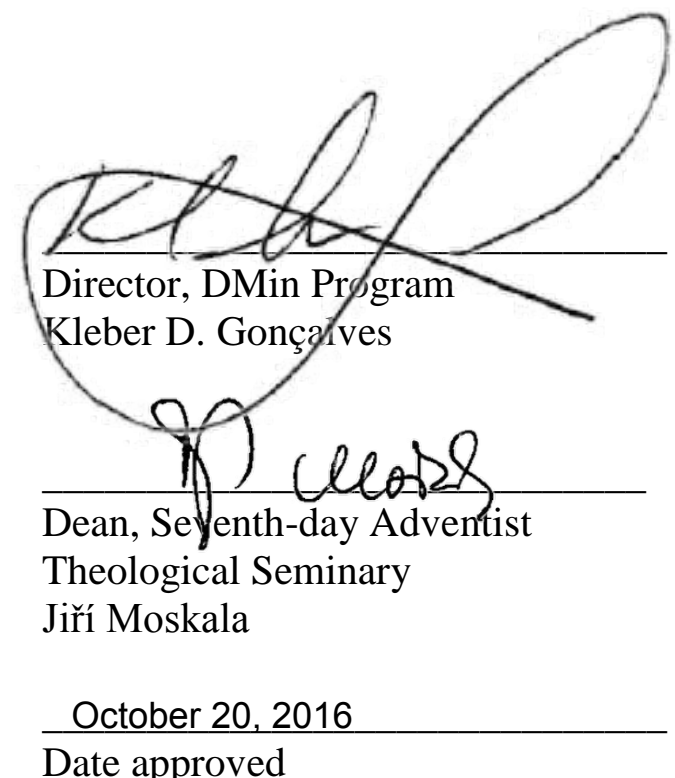

Date approved 
To my dear and precious wife, Irineide, who has been a constant source of support, encouragement and push.

To my sons Kaléo and Nicholas, my greatest earthly joy, who exempted me so many times from playing with them so that I could work on my project.

To my parents-in-law, Sebastião and Ana Rosa, strong and gentle souls, for their financial support and many prayers to make this dream come true;

to my mom, Eva, for cheering all the time.

And I thank God for guiding me until here. To Him all honor and glory! 
TABLE OF CONTENTS

LIST OF TABLES ................................................................................... viii

LIST OF TABLES $\quad$...................................................................................... viii

LIST OF ABBREVIATIONS ..................................................................... ix

Chapter

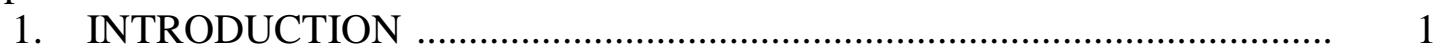

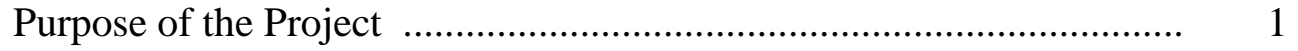

Justification for the Project ...................................................................... 1

Delimitations ................................................................................... 2

Definitions ................................................................................

Methodology ....................................................................................... 6

2. SPIRITUAL AND THEOLOGICAL FOUNDATIONS ................................. 9

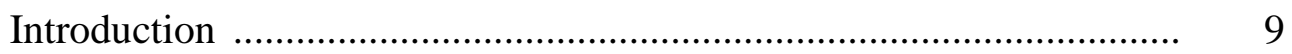

The Great Commission: Making Disciples .............................................. 9

Models of the Church: Fortress and Salt ........................................ 11

The Art of "Fishing" People .......................................................... 12

The "Hook" Must be Properly Baited ............................................... 13

Some Classes are More Difficult .................................................. 14

The Wealthy .......................................................................... 15

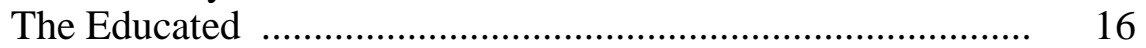

The Youth ............................................................................... 18

Jesus’ Method: Incarnational Ministry..................................................... 19

The Necessity of Adapting the Church for the Mission.......................... 20

New Wine in Old Wineskins? ..................................................... 22

Differences are not to Divide but Unite the Church ....................... 25

Many Members, One Body ……………………………............... 27

The Necessity of the Holy Spirit ............................................................ 28

The Necessity of Training the Church …………….............................. 29

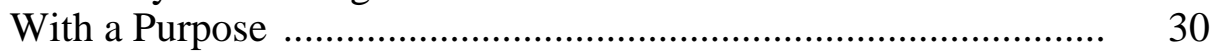

With Different Methods ............................................................. $\quad 30$

Conclusion .................................................................................... 31

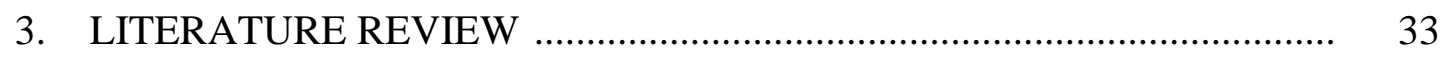

Growing With a Gap ..................................................................... 33 
Traditional Methods: No Longer Effective ...........................................

Fishers, Baits, and Different Kinds of Fish ............................................. 35

Defining the Postmodern "Worldview" ................................................ 36

The Premodern Era: God and the Church at the Center......................... 37

The Modern Era: Human Reason at the Center ……………………..... 39

The Postmodern Era: Nothing at the Center .......................................... 41

Main Characteristics of Postmoderns and Respective Difficulties For the Church …….......................................................... 42

Negation of Absolute Truth .................................................... 42

Distrust of Institutions........................................................... 43

Sense of Community and Equality .......................................... 44

Experience Before Reason...................................................... 45

Particular Characteristics of Postmoderns in Brazil........................ 46

Adapting the Church or Planting Postmodern-Friendly Ones?............... 51

Adapting the Already-Existing Church........................................... 52

The Family Model Church....................................................... 53

Special Programs Performed by Special Ministries................. 54

Small Groups as "Subcultures Within the Church”................. 55

Planting Postmodern-Friendly Churches ……………………….... 57

Experiments in Brazil ......................................................... 59

Questionings and Concerns ................................................ 60

Training the Church to Narrow the Gap................................................... 61

Knowing ................................................................................... 61

Understanding the Postmodern "Worldview" ........................ 61

Understanding the Purpose of the Church ............................... 62

Being ............................................................................... 62

Doing ...................................................................................... 63

Conclusion.................................................................................. 64

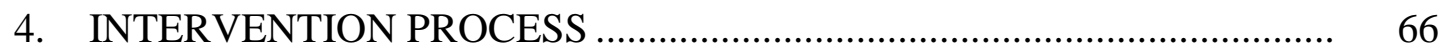

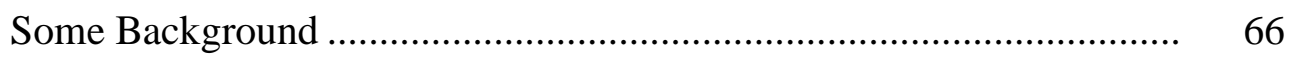

City of Curitiba ............................................................................ 66

Central Curitiba Seventh-day Adventist Church............................. 67

First Phase: Awareness of the Situation and Motivation to Act ............ 68

Calculating Limits ..................................................................... 69

Preparation ............................................................................ $\quad 70$

Sharing the Vision With the Church ............................................. 71

The Sabbath Right Before Moving ............................................... 72

Second Phase: Planting a New Church ................................................... $\quad 73$

The New Building ......................................................................... 73

First Meetings in the New Building ............................................... 74

Focus: Urban Evangelism ............................................................. 76

Purpose: Transforming Disciples Into Disciple-Makers.................. 78

Special Care for the Seventh-day Adventist Doctrines and

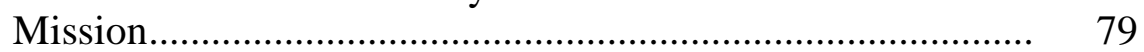

Adaptations to Fulfill the Mission............................................................. 82

General Adaptations ................................................................... 82

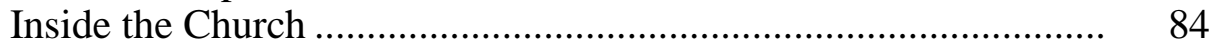


Sabbath School ................................................................ 84

Sabbath Morning Worship Service ....................................... 85

Special Evening Programs for Youth and Young Adults ....... 86

Bible Study Classes................................................................... 87

Outside the Church....................................................................... 87

Small Groups in the Houses................................................... 87

Ministries Serving the Community ……………………......... 88

Special (Urban) Ministries .................................................................. $\quad 89$

Already Functioning.................................................................... 89

Adventist Motorcycle Ministry (AMM) …………………...... 89

Walking and Running Ministry …………............................... 89

Ministry of Orientation in Creationism.................................... 90

Vegan Fair Ministry ................................................................ 91

Photography Class ……………………………………..... 92

English Language Ministry ................................................... 92

Worship in English ............................................................ 92

Sabbath School in English ...................................................... 93

Ministries Being Planned Next ............................................................. 93

"Exigent Love” Ministry................................................................. 93

"How to Stop Getting Fat" Ministry ………………….................... 93

Healthy Cooking Ministry …………….......................................... 94

Skaters' Ministry ……………………...................................... 94

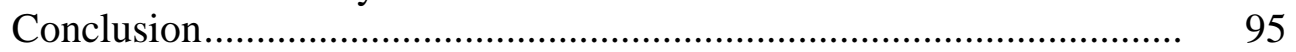

5. OUTCOMES AND EVALUATION ………………................................ 96

Outcomes at the First Church............................................................... 96

Outcomes at the Second Church ........................................................... 98

Tithes and Offerings ...................................................................... 101

Accessions Through Baptisms, Rebaptisms, and Professions of Faith.. 103

Diversity in the Accessions ..................................................................... 103

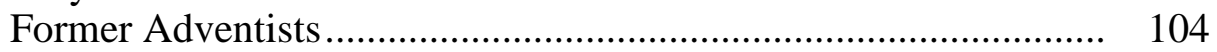

Atheists, Agnostics, and No Religion ……………………….......... 104

Evaluation.................................................................................. 106

What I Could Have Done Better ................................................... 106

I Should Have Established A Church Committee Sooner ...... 106

I Should Have Trained the Choir Members as Much as the

Core Members.

107

I Should Have Planned Better Strategies to Follow up on

Great Events.................................................................... 108

Positive Elements ..................................................................... 110

A Friendlier Church …………………...................................... 110

A Mission-Oriented Church ............................................................ 111

A Church That Works for the Community …………………....... 111

A More Interactive Church ........................................................ 112

Conclusion ........................................................................................ 112

6. SUMMARY, CONCLUSION, AND

RECOMMENDATIONS 


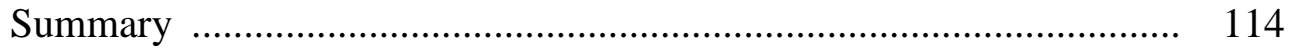

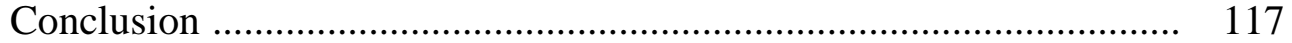

Recommendations ................................................................... 118

For Pastors and Church Planters .................................................. 118

For Church Conference Leaders ................................................. 120

The Book of Acts is Still our Model ................................................. 121

Appendix

FLYER WITH DAILY PROGRAMS FOR THE COMMUNITY ..................... 123

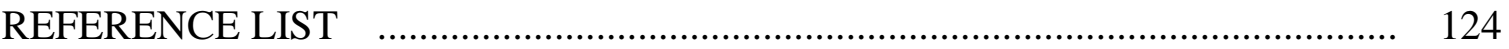

VITA 


\section{LIST OF TABLES}

1. Philosophical Worldviews in Christian History Since the Middle Ages ............ 37

2. Percentage of Religious Attendance in Brazil in 2007 and 2013 ..................... 50

3. Number of New Members in Curitiba Centra Church in the Last Years ............. 98

4. Diversity-inclusivity Showed in the Age of the Members of the Espaço Novo

Tempo Curitiba ................................................................................... 100

5. Comparison to Other Churches in a Spectrum Considered Postmodern Prone in Brazil

6. Ages of People Accepted in ENTC Through Baptism or Profession of Faith ..... 104

7. Former Religions of People who Became Members

\section{LIST OF FIGURES}

1. Religion proportions in Brazil's population in 2013 ..................................... 48

2. Tithes and offerings in 2014 and 2015 (in Brazilian Currency)........................ 102 


\section{LIST OF ABBREVIATIONS}

$\begin{array}{ll}\text { AMM } & \text { Adventist Motorcycles Ministry } \\ \text { ASP } & \text { South Parana Conference of the Seventh-day Adventist Church } \\ \text { ENTC } & \text { Espaço Novo Tempo Curitiba } \\ \text { SDA } & \text { Seventh-day Adventist Church } \\ \text { USB } & \text { South Brazil Union Conference of the Seventh-day Adventist Church }\end{array}$




\section{CHAPTER 1}

\section{INTRODUCTION}

\section{Purpose of the Project}

The purpose of this project is to train church members in the downtown area of Curitiba (Brazil) to update their evangelistic methods in order to include postmodern people and to plant a new church focused specifically on contemporaneous evangelism.

In this project, I want to help church members to become naturally more effective in their approach to secular people, and furnish pastors and missionaries with more strategies to include postmoderns in their evangelistic efforts. Finally, I hope with this project to disciple and baptize people in the big cities of southern Brazil who would never come to a church that works only with the traditional methods of evangelism.

\section{Justification for the Project}

Adventist evangelism in Brazil has succeeded for several decades in attracting and baptizing many people. However, the traditional methods have not reached people with a postmodern worldview, who are generally younger, wealthier, and more educated. In 2004, for example, in the district of Alto Maracanã in the state of Parana, Brazil, out of 103 people I baptized following the traditional methods, only two of them had a collegelevel education.

Furthermore, beyond the fact that the evangelistic methods are no longer effective for the new generations, church members do not understand the mindset of postmoderns. 
Consequently, the relevance of the Gospel is not being properly communicated to people in this situation. Thus, church members need to be informed about the current situation and trained to plan their evangelistic programs in such a way that people with a postmodern worldview may be also reached and included in the family of the church and in the proclamation of the Gospel.

Since it is increasingly more unlikely for postmodern people to go to a church program, especially in a church building, the church must know how to: (a) work outside of its walls developing friendship; (b) adapt its indoor programs as much as it can within its local and cultural limits; and (c) plant a new church—one that is totally missional in its nature in order to reach mainly postmodern people.

As the postmodern condition becomes more common in Brazil, mostly because of the Internet, it is necessary to prepare the church today to include and disciple people in this condition before evangelism becomes as difficult as it has been for the church in the so-called cultural Western world.

\section{Delimitations}

Due to the large cultural differences between the extreme north and south of Brazil, this project is planned according to the local realities in the southern region of the country. Despite the fact that this project was developed in Curitiba, which is the capital of the state of Paraná, I believe, based on my studies and my previous experiences as a pastor in this geographic area, that this project would be effective in most large cities in the three southern states of Brazil. 


\section{Definitions}

There are some words and expressions that may need previous definitions due to their broad spectrum of possible meanings in the literature. The very term postmodernism, for example, is one of them. This present work will be using this expression to mean the socio-philosophical thinking or worldview that began around the 1970s (Bruinsma, 2014; Norman, 2007) and is characterized basically by the belief that there is no absolute truth. For people with this worldview, truth is only relative, depending on factors such as culture, time, region, and religion, among others. Every institution affirming that it knows absolute truth is seen as suspicious by postmodern people.

Despite the fact that the postmodern condition is not related to any specific age group or social level, in Brazil, where it is just beginning, its adherents are concentrated specially in three groups, as we are going to show in this work: youth; people with an academic degree or pursuing one at the college level; and, to a lesser degree, wealthy people (not necessarily rich, but in the high middle classes and above).

A Brazilian postmodern person is different from what has been shown in the literature about postmoderns in Europe or North America. Because of the strong influence of the Christian religion in Brazil, most secular people still go to church on special occasions such as baptisms, weddings, funerals, etc. They know about Jesus and His death on the cross, but do not have any knowledge about His mission or about the Bible, though Bibles are found open everywhere in Brazil: in commercial places, in some public buildings, in many houses, etc. They do not believe it anymore, or just think it is not relevant. But this situation is increasing the number of atheists in Brazil, which today 
is around $2 \%$ of the population. According to a poll performed by the Catholic University of Rio Grande do Sul, when only the "Generation Y" (16 to 34 years old) in the South of Brazil is considered, this number increases to 19 or 3\% (Pesquisa PUC, 2015a, 2015b).

Another important word to be defined here is missional. This word is used differently from missionary, which implies going far from home for mission work. Instead, the missional person and the missional church make mission in their day-to-day life. Everything they do is with the intention of making disciples. A church with a missional profile will not work only on the basis of attracting people through excellent programs. It will develop ministries to work outside of its walls to serve the communities around where it is planted and sow the seed of the gospel. However, it will not abandon the attractional mode, because the people who are reached by the church's missional efforts will come to the special meetings, and they must be impacted by the message to come back again.

The word discipleship refers to the intentional relationship a Christian has with another individual in order to help him or her to follow Jesus. This word describes two realities. First, before the conversion, discipleship is bringing the person to the desire to become a follower of Jesus—-this is equivalent to "making disciples." In other words, in this case, the person is being discipled to become a disciple. The second reality is discipleship of someone who has already decided to follow Jesus; the intention here is to grow, learning more every day about the teachings of the Master, obeying Him and ultimately becoming like Him (Luke 6:40).

The reader will find in this work some tension when it comes to accommodating the church for a contemporaneous evangelism or planting a new one from scratch. The 
existing church has a limit for what it can accommodate due to its very nature as a temple. There are not many things to do inside a temple beyond worship services. Therefore, the tension lies in accommodating to a point where the configuration of a temple is not disrespected.

Another tension in this work that is worthy to mention here in the beginning for the purpose of definition and clarity is on the issue of planting a new church for a specific group of people, whether it is approved by the Bible or not. It is a fact that the church needs to reach different groups of people in many different categories, such as age, worldview, ethnicity, language, etc.; and it is clear that this mission is easier to accomplish when the church is naturally identified with the groups where it is inserted (Stetzer, 2014). However, planting a church with the sole purpose of gathering together a specific group of believers and separating them from others is not approved by the Bible.

This is evident when we notice that, in spite of the many conflicts in the primitive church between different groups of believers, there was no command or even suggestion that they should worship in different churches according to their differences. There were conflicts between Jewish and Greek believers (Acts 6:1), between poor and rich (Jas 2:24), and between slaves and free people (Eph 6:5-9), but the order was that they stopped acting like that and stayed undivided as one (1 Cor 1:10; Col 3:11). Planting churches just to accommodate different groups of believers would split the church of God. Churches should be planted to reach people for the Kingdom of God. Thus, if there is no missional purpose, there is no reason for a church to exist. This is the reason for the tension within this text on the issue of planting or not planting new churches with a contemporaneous profile. 


\section{Methodology}

After reading about the postmodern condition in Brazil—a very scarce issue in the literature-and comparing it to the literature about the condition in Europe and North America, I presented to the president of my local conference a plan of evangelism for postmodern people in a Brazilian context. The plan consisted of training the church in downtown Curitiba for one year and then planting a postmodern-friendly church after that in order to baptize people who were not being reached.

Plans were made so that I could recruit and train some members of the Curitiba Central Church in 2013. This first part of the project was all about information, transmitted in the form of short seminars mainly about three subjects: characteristics of the postmodern condition, the mission of the church, and some possible strategies to reach postmodern people for Jesus. One year later, the conference leaders found a place for the birth of the second church, $10 \mathrm{kms}$ away from the mother church in the big city of Curitiba.

Research was done into the profile of the local community around the new church. After that, we made plans based on that profile to create ministries that could be relevant to local people. Many different ministries were developed in order to impact the community. These ministries were based on the talents of our local members, which were discovered through a test of gifts and on a previous list containing their jobs, academic graduation information, and even their hobbies.

The church building did not look like a church but like an events center, and it was open every day for different courses, programs, and services for the community led by volunteer professionals, including members of the church and people invited to help. 
Some of the programs were Bible classes and worship services. Worship services were short, with contemporaneous music as well as some from the hymnal, but more accelerated. Sermons were also short but powerful, always beginning with some illustration from the visible world and concluding with visions of the invisible but real world, always inviting people to have a real experience with God.

At the end of 2014 and 2015, I got data from the Union Conference with statistics about the age and academic background of all baptized members in that region to compare with the baptized and active members of the second church. According to the data, the second church baptized and accounted for more members in the postmodern range than any other church in the local conference or the Union Conference, except the churches in the universities.

In this work, chapter 2 will present a theological reflection for this project based on (a) the mission of the church to reach all kinds of people; (b) the acknowledgment that some classes are more difficult to reach than others; (c) the instructions of Ellen G. White about evangelism; and (d) the necessity of developing special and differentiated evangelistic plans for the different classes.

Chapter 3 will review the current literature in order to understand the postmodern "worldview," as well as the different plans suggested by specialists on how to approach and disciple postmoderns and how the church in Brazil is proceeding with this challenge.

Chapter 4 presents the strategy used in training volunteer members of the Curitiba Central Seventh-day Adventist Church to adapt their approach methods and plant a daughter church with an urban missional focus. The strategy for the new church is also described in this chapter. 
Outcomes and evaluation are presented in Chapter 5. Since it is difficult to precisely define the postmodern condition in Brazil, but given its strong relation with youth and education, the success of this project is measured by the number of baptisms of people aged 18-35 and people who are studying for or have completed a college degree. Finally, the proportion of people in these specific demographics in relation to the local members is contrasted against the average proportions of all the other churches in the local conference and union conference.

This project was completed in December 2015. 


\section{CHAPTER 2}

\section{SPIRITUAL AND THEOLOGICAL FOUNDATIONS}

\section{Introduction}

The Seventh-day Adventist Church identifies itself with the three angels of Revelation 14, with the mission of preaching the "everlasting Gospel” (v. 6) to all the earth, specifically to “every nation, and kindred, and tongue, and people.” However, there is a group of people that is not being reached by the church: postmodern people.

Despite the fact that they are recognizably more difficult to be reached, they also have spiritual needs. Therefore, in order to accomplish its mission, the church must make plans to reach this group of people and give them the opportunity to hear the good news of salvation.

This chapter will discuss (a) the biblical and spiritual foundations for creating a desire in the Brazilian church to reach and include all people, including unchurched postmoderns; and (b) examples from the Bible of how the church adapted its approach at crucial moments so that people of different worldviews (i.e., Greeks and Jews) could be reached and saved.

\section{The Great Commission: Making Disciples}

Go therefore and make disciples of all the nations, baptizing them in the name of the Father and of the Son and of the Holy Spirit, teaching them to observe all things that I have commanded you; and lo, I am with you always, even to the end of the age.

(Matt 28:19-20) 
We take it for granted that we already understand the verse above. However, before we proceed, I believe we should give it a fresh look in order to understand what it really demands of us, based on the strength of its original language.

In Greek, the verb translated here as "go" is actually a participle in the aorist form (poreuqe,ntej, poreuthentes). As it is a temporal adverbial participle, it could be rendered as "after going," "when going,” "as you are going,” or “gone.” Against this interpretation especially in this verse, Wallace (1996, p. 645) says, "to turn poreuqe,ntej into an adverbial participle is to turn the Great Commission into the Great Suggestion.”

In fact, there is a situation that linguists call "attendant circumstance,” which would put this participle in function with the main verb of the sentence - the imperative finite verb "make disciples" (maqeteu,sate, matheteusate) - and it would then assume an imperative meaning, as above: “Go [and] make disciples.” Since the word "and” is not original, the translation “Go make disciples!” is also possible.

Wallace (1996, p. 645) has a good point showing that "in Matthew, in particular, every other instance of the aorist participle of poreu,omai [Gr., 'to go'] followed by an aorist main verb (either indicative or imperative) is clearly attendant circumstance” (see, for example, Matthew 2:13 and 9:18, as well as Luke 17:7 in pages 640-642).

Regarding the other two verbs (“to baptize” and "to teach”) in this sentence, the following must be considered:

The other two participles (bapti,zontej, dida,skontej) should not be taken at attendant circumstance. First, they do not fit the normal pattern for attendant circumstance participles (they are present tense and follow the main verb [in this case, “to make disciples”, cf. p. 630]). And second, they obviously make good sense as participles of means; i.e., the means by which the disciples were to make disciples was to baptize and then to teach. (Wallace, 1996, p. 645) 
The most important point in all this observation is that, no matter how the verb "go" should be interpreted (as temporal participle or as imperative), virtually all linguists agree that the main verb of this whole sentence is "make disciples.” All the other verbs of this verse (including the problematic participle poreuqe,ntej, "going”) are syntactically subordinated to it.

In short, no matter how the first verb is understood, Jesus' order is not “Go baptize!” or "Go teach!” as sometimes we as church seem to prioritize, but rather "Go make disciples!”- which will naturally result in baptism and teaching. With this imperative Jesus commissioned all His followers to not only be messengers delivering His word of salvation, but to also create relationships, eventually turning friends into disciples-His disciples. Then comes baptism and a lifelong commitment to be always teaching and at the same time learning "all things" that Jesus commanded us to do.

\section{Models of the Church: Fortress and Salt}

Paulien (2008, p. 121) summarizes this mission of the church using two models: the fortress model, like a city over a mountain that cannot be hidden, working as a lighthouse (as in Matt 5:14); and the salt model, involving itself completely with the masses in order to transform them (as in Matt 5:13). Based on these two models, he affirms that much has been made of the "fortress" model, but the church has failed in the "salt" model of carrying out its mission.

Thus, for a number of reasons, there are some classes who are not being attracted to the church and who are not being reached with our message of the Gospel, being at risk of losing their opportunity for salvation. Most of these classes are considered as being generally part of a larger contemporary group: postmodern people. But no matter 
how they are labeled, these people are being neglected and missed, not because they are eviler than others, but because the church is not "speaking" their "language" in order to communicate meaning, create a strong relationship and become able to disciple them.

The "salt" model of being church happens when we get mixed with people outside of the "fortress" - the church building. This model is seen in the Bible when it displays, for example, Christians influencing fellows at the ordinary work-be it fishing or tent making (Acts 18:3). It is also seen when they are sharing meals together (Acts 2:46, 47), participating in wedding parties (John 2:1-2), and in many other relations (Eph 6:1-9). It is first being salt that we can eventually become "fishers" of people for the “fortress" of the kingdom of God.

\section{The Art of “Fishing” People}

Even before giving the Great Commission, Jesus had already said He would transform His followers into "fishers of human beings" (Luke 5:10). Unlike the parallels in Matthew 4:19 and Mark 1:17, where the noun "fisher" (a 'lieu,j, halieus) is used, in Luke 5:10 the word translated as "fishers" is from the verb zogreo (zwgre,w, zogreo), which means “to catch alive," "to bring to life,” or even "to bring back to life” (Bovon, 2002, p. 171). Marshall (1992) suggests, “Luke’s wording is used instead in order to avoid the negative implications that might be detected in 'fishing for men'” (pp. 205, 206).

This verb is used in the Greek version of the Old Testament, the Septuagint (LXX), with the meaning of "saving persons alive from danger," as found in Numbers 31:15,18 and Deuteronomy 20:16 (Marshall, 1992). There is also evidence of a secular 
use of the fishing metaphor to mean the "catching of people” in order to save them (Nolland, 1989).

In addition to the former information, Wuellner (1967) observes in his book The Meaning of "Fishers of Men" that the metaphor of fishing for men had been used long before by Plato and in the Hellenistic world in reference to teachers or philosophers who would "catch" their students with "baits of wisdom". Therefore, the idea of "fishing for men” was not originally coined by Jesus. Thus, it is very likely that the disciples understood it in its appropriate background context, meaning both "to save people from danger" as in the Old Testament usage and "to make disciples" as in the Hellenistic usage (Robbins, 1982).

Curiously, in 2 Timothy 2:26 this metaphor has a negative meaning, as it is used to mean the work of the devil to capture people alive. In this sentence, this word contrasts the work of Jesus with the work of the devil: this one captures people alive in order to kill them, while Jesus wants them alive in order to save them (Wuellner, 1967).

To extend the use of this metaphor, it is a fact that fishers need different baits to catch specific kinds of fish. Also, some fish are more difficult to catch than others and demand different skills, techniques, and tools. Likewise, just like fish, people are different, and the church must furnish the proper "baits" and teach the proper techniques for "catching” different groups of people. Otherwise, there will be no interest on the part of these people in coming to church and eventually becoming active members in the body of Christ. 
The Hook Must be Properly Baited

"Let us not forget that different methods are to be employed to save different ones” (White, 2002, p. 106).

In order for the church to appropriately fulfill the role of fishers of human beings to "catch them alive" in order to save them - there must be an intentional and continuous effort from the leaders of the church to teach members about the different worldviews and motives of the different groups of people around them.

Using Jesus’ fishing metaphor, Ellen G. White (2002) points out the failure of the church in not using different methods to accomplish its mission. She says that the "hook" must be properly "baited” and that “ways and methods are not prayerfully devised” by the church to reach different classes of people (pp. 105, 556).

Furthermore, she affirms that God's workers must be able "to see and sense that their words and their advocacy of truth must vary with the class of people they are among, and the circumstances that they have to meet” (White, 2002, p. 106).

\section{Some Classes are More Difficult}

Jesus Himself mentioned one class that was more difficult to convert than others, and still is today: wealthy people (Matt 10:23). The church, which is mostly made up of poor or “common” people (White, 2002, p. 325), has noticed their absence in its ranks, too.

But beyond rich people, there are other classes today that are difficult to reach as well. As already mentioned in the introduction to this dissertation, the so-called postmodern worldview in Brazil is mostly_-but not exclusively_linked to three groups: the wealthy, the academically educated, and a growing number of teenagers and youth, 
influenced by the mass media and the academic environments that promote and grows this worldview in their minds (Paulien, 2008, p. 11). These groups are not being affected by our ordinary evangelistic strategies, which succeed very well for middle class as well as for poor and uneducated people. Thus, in the words of White (2002, p. 556), the church is probably failing because "there is a certain round of labor performed in a certain way that leaves a large class untouched.”

\section{The Wealthy}

As mentioned before, among the three special classes we are discussing, Jesus Himself mentioned wealthy people as being very hard to convert. He said, "How hardly shall they that have riches enter into the kingdom of God!” (Mark 10:23). Given the high importance attributed to rich people in those times, the disciples did not understand the meaning of what Jesus said. The text mentions that first they "were astonished" (Mark 10:24) and then "astonished out of measure” (v. 26, Gr. perissw/j, perissos, “abundantly,” “exceedingly”) by His words.

Jesus explained that the problem actually was not being wealthy, but "trust[ing] in the riches.” This clarification is very important in order to confirm what He taught elsewhere: actually, the problem is where the heart is (Matt 6:21). Likewise, Paul says the problem is not in the money itself, but in loving it (1 Tim 6:10). According to White (2002), converted wealthy people, "who have their Lord's money, will be moved by the Spirit of God to open doors for the advancement of the truth in large cities” (p. 87).

But, given their old known resistance to accepting the Gospel message, the rich have been neglected in great part by the church in its general evangelistic efforts. Thus, White (2002) appeals for a strategy in this direction: 
We talk and write much of the neglected poor: should not some attention be given also to the neglected rich? Many look upon this class as hopeless, and they do little to open the eyes of those who, blinded and dazed by the power of Satan, have lost eternity out of their reckoning. Thousands of wealthy men have gone to their graves unwarned, because they have been judged by appearance, and passed by as hopeless subjects. But, indifferent as they may appear, I have been shown that most of this class are soul burdened. There are thousands of rich men who are starving for spiritual food. Many in official life feel their need of something which they have not. Few among them go to church; for they feel that they receive no benefit. The teaching they hear does not touch the soul. Shall we make no personal effort in their behalf? (p. 555, italics added).

Since this kind of evangelism demands hard and long work, and generally the number of baptisms in the end is very small, we tend to go evangelize mostly among the poor people, who accept the message easier and generally faster. It will, no doubt, always be difficult to reach the upper classes. But the truth will often find its way to them if we first reach and train the middle and poorer classes (White, 2002, p. 417).

Yes, people are much more difficult to attract than fish, since they have free will. And, as we have been discussing here, wealth makes it even more difficult. But, empowered by the Spirit of God and following the revealed divine instructions faithfully, the church—even at the lowest social level—can influence the upper classes to join the family of God (cf. Eph 2:19).

\section{The Educated}

Another class that is being increasingly more difficult to reach is the academically educated (Paulien, 1993, pp. 27, 161). Because they have apparently more knowledge and more access to information which they need to match all together, they begin to question some important things, and if the church is not prepared to address these questions, it will never become relevant or interesting to them. In this sense, the Bible is 
clear in admonishing us to "be always ready to give an answer to every man that asketh you a reason of the hope that is in you" (1 Pet 3:15).

People with more education have been difficult to convert since early times (Acts 17:18-21, 32-34). Even those who are in the church, if their Bible knowledge is only superficial, will abandon it as soon as they see any conflict with the "false knowledge" of the world (1 Tim 6:20). Paul was already advising people in the early church that this kind of knowledge (the one that despises God and His word) had caused some of them to leave the church (v. 21).

Christ shed His blood for these people as well, and they must also be invited to come to His side. But, like the church has been doing with the wealthy, as mentioned above, also "the intelligent, the refined, are altogether too much passed by. The hook is not baited to catch this class, and ways and methods are not prayerfully devised to reach them with truth that is able to make them wise unto salvation (White, 2002, p. 556).

The apostle Paul worked with this class, and he was equipped to talk to them "in their language.” Before using the Bible as an authority when talking to them, he used their own arguments and even mentioned some of their philosophers (Acts 17:18-31). From that point on, he brought to his listeners the first rays of light and knowledge of the true God of the Bible.

However, even Paul the apostle learned much from his struggles to reach the intellectuals of his time. At first, he used much of his skills in rhetoric trying to reach a platform where he would be accessible to them. But he noticed that this approach won only few in numbers (Acts 17:32-34). Then he learned that the Gospel actually must be presented in a simple way to be clearer (White, 2008). He said to the Corinthians that in 
his new approach, even to the academic, he was now "determined not to know anything among you, save Jesus Christ, and Him crucified” (1 Cor 2:2). In the same way, White (2009) proposes:

Thousands of hearts can be reached in the most simple, humble way. The most intellectual, those who are looked upon and praised as the world's most gifted men and women, are often refreshed by the simple words that flow from the heart of one who loves God, and who can speak of that love as naturally as the worldling speaks of the things which his mind contemplates and feeds upon. Often the words well prepared and studied have little influence. But the true, honest words of a son or daughter of God, spoken in natural simplicity, will open the door to hearts that have long been locked. (p. 124)

The church must have a vision and a desire to reach educated people and show them "Jesus and Him crucified." After they are converted, they will bring others like them: people who need to match all the knowledge and information they have been receiving in their education. These new converts are crucial for bringing in others because they understand how they are trying to fill some gaps of knowledge, searching for connection and meaning.

\section{The Youth}

The third group considered to be difficult to reach is the postmodern youth and young adults. It is important to mention again that the postmodern demographics and configuration in relation to church in Brazil are very different from what literature has been showing in North America: while the North American church has experienced a shortage of young members, $50 \%$ of the members of the Adventist church in South America are less than 35 years old and 20\% are less than 17 years old (Kohler, 2012). In this sense, youth in Brazil are not leaving the church nor missing in it as they are in the USA, but as the postmodern worldview grows in Brazil, they are becoming increasingly more difficult to reach. 
The church has a great responsibility to work with the youth, discipling them and training them in order to keep them strong in their spiritual lives and so that they might bring others like them as well. "With such an army of workers as our youth, rightly trained, might furnish, how soon the message of a crucified, risen, and soon-coming Savior might be carried to the whole world!” (White, 1943, p. 43).

\section{Jesus’ Method: Incarnational Ministry}

Since Jesus is our example (John 13:15), we should observe His methods of approaching people in order to follow Him as individuals and as a church:

Christ's method alone will give true success in reaching the people. The Savior mingled with men as one who desired their good. He showed His sympathy for them, ministered to their needs, and won their confidence. Then He bade them, "Follow Me.” (White, 2003, p. 143)

Another important quotation in this direction is this:

Christ drew the hearts of his hearers to Him by the manifestation of His love, and then, little by little, as they were able to bear it, He unfolded to them the great truths of the kingdom. We must also learn to adapt our labors to the condition of the people - to meet people where they are. (White, 2002, pp. 484-485)

As in the time of Jesus, people still need others to help and encourage them, as well as real relationships. Burrill (1998) summarizes it by saying that the Gospel "is not to be shared outside of a relationship" (p. 230). That's why it is important that the church keep meeting people's needs with actions, not just as an institution, but as fellow neighbors. Not only in the programs of the church, but in the practical day-to-day life.

Local pastors may help to awaken this attitude in their churches by preaching and creating ministries where members can serve according to their respective talents and dispositions, as seen in Acts 6:3, 4. These ministries may perform their tasks in the church or outside of it, going to where people are, and according to their needs. For those 
in need of bread, for example, there was a ministry of distribution of food for both Jews and Greeks (Acts 6:1-6); for those with intellectual needs, Paul ministered in a certain school of Tyrannus for two years (Acts 19:9,10).

After having contact with Christians, people should be confident that they are good and privileged people. They should then, in the proper time, be invited to their church, where they should feel like part of the family. And the church in turn should be prepared to receive them with a more contemporary worship service to speak in their language so that they can understand the message and appreciate it.

\section{The Necessity of Adapting the Church for the Mission}

If the early church had not created some accommodation for the inclusion of the Gentiles, these ones would be forced to perform many rituals without any meaning for them, like circumcision, ablutions, and other things dictated by Jewish tradition. Only after praying and discussing the issue in the first council of the Church (Acts 15) the leaders decided that the Gentiles should abstain only from "things offered to idols, and from blood, and from strangled, and from fornication” (Acts 15:19,20; 21:25). It is implicit, however, that the observance of the Sabbath, which is part of the Ten Commandments, was also part of their new life as Christians (Heb 4:9; Jas 2:10-12; 1 John 2:3,4, etc.). Thus, the Gentiles became more accessible to receive the message of salvation with all its meaning.

Accordingly, an accommodation to the local culture is necessary today as long as it does not compromise principles and commandments, according to the teachings of the Holy Scriptures, as taught by church. However, there must be care on the part of the leaders, because "many examples of faulty adjustments demonstrate that accommodation 
has been more a compromise of the faith than an adaptation to the culture” (McGavran, 1974, pp. 42-52; Dorneles, 2006). For White (2010), this danger is real and Adventists have been warned:

"There is a constant danger that professing Christians will come to think that in order to have influence with worldlings they must to a certain extent conform to the world. But though such a course may appear to afford great advantages, it always ends in spiritual loss” (p. 570).

The most important adaptation in the church is in its members themselves: in their attitude toward unconverted people. Our approach to other people should make them see us as loving people who care about others, like Jesus did. He expects the same from us as well (John 13:35). With this in mind, we will notice the need to adapt our language so that we do not sound arrogant, aggressive, or prejudiced. In church ministries or services, personal conversations, sermons, and songs must be comprehensible, reasonable, inspiring, and powerful. Our church language must be so clear that there is no miscommunication. That is certainly why the deacons who were chosen to include and help the Greek widows in Acts 6 were all people with Greek names, who we can assume understood the Greek culture and spoke their language fluently (v. 5).

Today, when it comes to evangelizing a growing postmodern society, some churches will find it difficult to adapt in such a way that postmodern people feel welcomed and comfortable in their services. Thus, visitors may not understand the formality of the parts and the words enough to pay attention to the message and accept it in their lives. In this case, the pastor must plan an evangelistic mission with members who understand postmodern culture. Those who are going to serve on this mission must have the same profile as those first Greek deacons: they must be people "of honest report, full of the Holy Ghost and wisdom,” and “full of faith” (Acts 6:3 and 5a). 
Planting new churches with a missional purpose in places where postmodern culture is growing will motivate young and postmodern people to work together with their pastor in planning evangelistic programs to target their friends.

This approach may be criticized, but Ellen White, one of the pioneers of the Seventh-day Adventist Church, thinking on the spreading of the message and the proper growing of the church, advises: "Those who do not discern and adapt themselves to the increasing demands of the work, should not stand blocking the wheels, and thus hindering the advancement of others” (White, 2002, p. 104).

\section{New Wine in Old Wineskins?}

The Bible texts most often used to support the idea of different churches for different worldviews (mainly the postmodern) are the ones related to the "new wine in new wineskin” lesson (Matt 9:17; Mark 2:22; Luke 5:37,38). These texts display the second of a pair of parables known as the "Twin Parables"-which occur in all the three Synoptic Gospels. The first parable deals with the inefficacy of sewing new pieces of cloth in an old garment trying to preserve it. And the second one deals with the inefficacy of putting new wine into old wineskins, for the same purpose of preservation. Even though both parables appear together in all the three Synoptic Gospels expressing the same principle, the second one, about wine and wineskin, is the most used.

A number of commentators understand the "new wine" as a new worship style to meet the needs of the contemporary people. This "style" of worship would be more informal, include the use of more contemporaneous music with comprehensible lyrics, the use of more videos as illustrations, and the performance of impacting sermons for the day-to-day life. The "old wineskins" in this case are the "old" churches with their "old" 
system of worship and evangelism (Mannion, 2007; Gladden, 2000: 14). Thus, according to this interpretation, the new model of worship and evangelism should not be performed in traditional churches lest they both—new style and old church—be damaged (Mark 2:22).

It is an interesting interpretation and it makes sense. However, there are two important points that must be observed in regard to this parable. First of all, some commentators recognize that they do not know the exact meaning of these parables. The meaning of this metaphor is so vague that Cranfield (1959, p. 113) alone suggests five possible interpretations, among many others in the commentaries on that passage. The literal relationship between wine and wineskin seems to have a natural common-sense meaning that can be applied to other situations. But which is the specific one Jesus intended? We cannot affirm categorically that Jesus was specifically referring to church buildings (or people in their congregations) as "wineskins" and their worship styles as "wine."

Some believe the meaning of these parables may be connected to the previous event, the "fasting issue", which appears immediately before our passage in all the Synoptics (Matt 9:14-17; Mark 2:18-20; Luke 5:33-35). If there is any connection at all between them, the meaning then might be that the "new wine" means the Gospel of Jesus in the New Testament and the "old wineskin" is the Jewish system, which was not accepting Jesus as the Messiah (Bock, 1994).

The second point is that Jesus used two different words for "new" in the original Greek: neos when referring to the wine and kainós when referring to the wineskin. Neos means new but the same, or renewed; kainós means new but different, a fresh one. In this 
case, the "new (neos) wine" is actually not "fresh" or "brand new": it is the same product from the vineyard, but somehow renewed or maybe experienced differently. But it must be put in a fresh, brand-new, never-used-before (kainós) wineskin.

Thus, if the application of the parable is really about the essence of the message (wine) and its church-container (wineskin), then, according to the text it would mean that the message is actually the same, but renewed and adapted or accommodated in order to be freshly experienced. On the other hand, the congregations, as the containers (wineskins) of the message, should be totally "new" in order to not damage both the message itself and the congregation of worshipers, which would split and fall apart.

This should not be understood only as the necessity of creating new separate churches for a postmodern "style” of worship. The word kainós ("new”), used in reference to the wineskins, is the same word used in the Bible when referring to human beings who are transformed into "new” people by the power of God. Thus, when applied to the church — which is actually the people of God rather than the building — it must have the same meaning: a church made up of people totally transformed into a fresh new people, who are being sanctified by the Holy Spirit and who love the lost. With such converted people driven by the Spirit of God, the old message of a risen and about-tocome Savior will be contextualized, refreshed and renewed for these times, in order to be proclaimed according to the understanding of the current generation, and to all groups of people as well. Thus, Jesus’ meaning in the parable of the wineskins is not about separation, but about transformation. We need to be transformed in totally new wineskins in order to receive the same good old Gospel, just renewed or adapted for these times. 
There is another interesting aspect of this parable that people generally do not notice, which must also be true in its application to real life: the new wineskins are supposed to bear old wine as well, without any damage. The problem is not in the wine, but in the container-whether it can or cannot bear the wine without bursting.

Furthermore, if the parameters of this parable are followed to the end, one needs to recognize the important point that, according to Jesus, "no man having drunk old wine straightway desireth new: for he saith, the old is better” (Luke 5:39). Maybe Jesus was using some irony here or just repeating people’s opinions, since the wine He drinks and offers as the best is actually the new wine (see Luke 1:15; Mark 14:25, 15:23; Matt 26:29). But, somehow, according to this parable, people prefer the old. It is "better," say people who tasted it. Anyways, we need new wineskins: churches made up of people totally converted and transformed by the power of God in order to love and include any class of people.

\section{Differences are not to Divide but Unite the Church}

The Bible does not hide the fact that the different classes and castes of the early church sometimes faced serious problems when worshiping together. For example, James (2:1-13) mentions the fact that the rich and the poor faced problems in the church. But they were not commanded by him to split in two different churches, one for the poor and the other for the rich: instead, they were commanded to stop acting like that.

Likewise, in Corinth, there was the issue of likely former prostitutes from the famous Aphrodite’s temple in Corinth (Champlin, 2002, p. 1; Nichols, 1957, p. 656) who were converted and now were worshiping together with the Christians (1 Cor 6:9-11). Their appearance—probably their short hair (Champlin, 2002, p. 175)—was a 
demonstration in that time and region that they had been former prostitutes. Thus, in order to avoid any confusion, they were told to wear veils (1 Cor 11:6-15). This order is not given to any other church in the Scriptures (1 Cor 11:16). It was possibly an "adaptation" to the local culture in order to have all worshiping together without the risk of causing any misinterpretation about the real character of the Christian community, and probably in order to have these women protected and included.

There is not in the Bible any instruction to separate the worshipers into specific churches of slaves, or free people, or rich people, or Gentiles, or Jews, much less of former prostitutes. The leaders of the church had to face the situation and exhort them to live together in peace and sanctification. I believe it was not easy, but separating certainly would not help—on the contrary, it would dismantle the church very soon into "separate bodies” of Christ.

However, it is natural that people get closer to each other when they find similarities. People come together when they share common affinities. A church with many young people will naturally attract more young people, while more traditional people will prefer to meet with others like them, forming more traditional churches.

Therefore, they meet together not only because they have different "styles” of worship; they meet together in specific, local, regional, missional churches, for a purpose. They meet together to bring others like them, for a mission, with the vision of being part of one body, communicating with all other parts in a healthy way.

Constant communication among the churches is important to preserve unity (Col 4:16; Acts 16:4, 5). For example, the church in Corinth had a specific situation for women, a local social convention, in order to include former prostitutes and save them. 
Paul kept them aware of the condition: "we have no such practice; neither do the churches of God" (1 Cor 11:16). It seems that this was a specific practice for that church only, for communal and missional purposes.

It is also interesting how Paul tried to keep the churches connected to each other (Col 4:16) with the main principle of keeping the door open so that they could preach the Gospel (v. 3). This suggests that if churches are so connected today, with the same purpose of preaching the Gospel, they will not criticize each other as "liberals" or “conservatives" for meeting according to their similarities or differences. They will see each other as different parts of the same body, commanded by Christ, the Head, to perform evangelistic efforts in order to save people wherever they are.

\section{Many Members, One Body}

Even though there are so many differences from person to person and from social class to social class—not only in worldviews, but in "tastes," opinions, prejudices, traditions, etc. - the very fact that we worship the same God and share the same hope should keep us united as one strong body. After all, this is the appeal made by Paul the apostle to a divided church and to the church in the world of every time:

Now I beseech you, brethren, by the name of our Lord Jesus Christ, that ye all speak the same thing, and that there be no divisions among you; but that ye be perfectly joined together in the same mind and in the same judgment. (1 Cor 1:10)

The word translated here as "divisions" is the Greek schisma, which can be also rendered as "schism." The church members in Corinth were divided into at least three parties. There was one group that preferred Paul's style of preaching and leadership; another group preferred Apollos instead; and another group was for Peter's style (1 Cor $1: 12 ; 3: 4)$. 
Another motive of division in Corinth is also noticed in chapter 11: The Holy Communion, or Holy Supper. "For first of all, when ye come together in the church, I hear that there be divisions [schisms] among you" (1 Cor 11:18). Finally, this word is used a third time in the epistle, but now in the context of an exhortation. The church is compared to a body, where no schism can occur without damaging the whole body:

That there should be no schism in the body; but that the members should have the same care one for another. And whether one member suffers, all the members suffer with it; or one member be honored, all the members rejoice with it. Now ye are the body of Christ, and members in particular. (1 Cor 12:25-27)

Therefore, the inspired counsel is that the church, even though it is made up of different groups with different worldviews, social classes, tastes, and preferences, should be united in one body, without labeling churches as "traditional" or "postmodern" in the sense of belittling any of them. The members of our congregations should see all churches—including their own—-through missional lens, as different places not only to worship and grow in community, but to reach different people as well. They all have the same purpose: preaching the everlasting Gospel as a united remnant church, sharing the same doctrines and principles, being salt and fortress wherever they are, and accomplishing their mission.

\section{The Necessity of the Holy Spirit}

We may try to copy or adapt all the methods used by the primitive church and yet fail horribly if we do not recognize that these methods were originated and guided by the Holy Spirit. When re read the fifth book of the New Testament, we must notice that it is not about the Acts of the Apostles, as it is called, but about the acts of the Holy Spirit guiding and empowering the first Christians in their mission. 
The active presence of the Holy Spirit is explicit right at the beginning, in the second verse of the book. In the eighth verse of the same chapter, in a promise made by Jesus, there is registered the key to all the victory of the church: "But ye shall receive power, after that the Holy Ghost is come upon you: and ye shall be witnesses unto Me” (Acts 1:8). The Holy Spirit is mentioned around 50 times in the book in many different instances: He gave commandments to the apostles (1:2), gave them spiritual gifts (2:4, 38), filled their hearts (4:8; 31); enabled them (6:3, 10; 7:55); guided them (8:29; 13:4); performed miracles (8:39); instructed them (10:19-20; 13:2); made decisions (15:28); changed their strategies (16:6,7); etc.

It can be no different with the church today. We must never forget the only source of power that enables us to do evangelism in any circumstance. As a church, we can start great projects, apparently coming from heaven, but if we dare to work without the Source of all life and power, our projects will be only a series of events with no significant results. Every member of the church must be humble and depend on God, asking Him to do His will through our lives and through the church.

\section{The Necessity of Training the Church}

"The congregations to whom he [Paul] wrote had many problems in common with our churches today. The urban conditions of Corinth and Chicago overlap to some degree” (Bakke, 1987, p. 80).

The early church had to be trained to take a specific approach to a new situation: the coming of the Gentiles. After the council in Acts 15, Paul and Barnabas went to the churches "informing to the brothers what they had decided" in regard to the Gentiles 
(Acts 16:4). In other words, the churches were receiving information about how to proceed with this new issue. They were being trained.

We must do the same about the postmodern society we live in today. Even for the young converted postmoderns who are already members of our churches, training them in how to proceed will give them direction and motivation to be more effective in reaching others.

We have an army of youth today who can do much if they are properly directed and encouraged. We want our children to believe the truth. We want them to be blessed of God. We want them to act a part in well-organized plans for helping other youth. Let all be so trained that they may rightly represent the truth, giving the reason of the hope that is within them, and honoring God in any branch of the work where they are qualified to labor. (White, 2009, p. 30)

\section{With a Purpose}

The members of the church must be made aware by means of constant reaffirmations via pulpit and coaching that its purpose of existing goes beyond meeting in a given building to worship. They are lamp and salt (Matt 5:13-16), and they have a mission (Matt 28:19,20), which is represented by 3 angels in Revelation 14:6-12. They have to come together and plan ways to work and behave in church in order to fulfill that mission, becoming "fishers" or "disciplers" of human beings.

Some authors believe that just this acknowledgment - that the church is not the building or the organization, but the very community of believers (1 Pet 2:4,5) - will make a huge difference and will create an environment in which the purpose of the church is accomplished naturally (Hunter, 2000, p. 75; Oliveira, 2009, pp. 22,23). 


\section{With different Methods}

The members of the church must create different methods in order to achieve their purpose—reaching the hearts and discipling people, including the difficult postmoderns. White (1952) affirms:

Unless there are those who will devise means of turning to account the time, strength, and brains of the church members, there will be a great work left undone that ought to be done. Haphazard work will not answer. We want men in the church who have ability to develop in the line of organizing and giving practical work to young men and women in the line of relieving the wants of humanity, and working for the salvation of the souls of men, women, youth, and children. (p. 105)

Curiously, she asserts, "there must be no fixed rules” because "our work is a progressive work, and there must be room left for methods to be improved upon. But under the guidance of the Holy Spirit, unity must and will be preserved” (White, 2002, p. 105). She believed that if the church had the purpose of approaching the lost, God would open doors for them to create methods that would succeed; and that these methods might be different from the traditional ones:

'Means will be devised to reach hearts. Some of the methods used in this work will be different from the methods used in the work in the past; but let no one, because of this, block the way by criticism.' (White, 2000, p. 105)

Today, a hundred years after Ellen White wrote this text, it is past time for us to finally understand, as a missional church, that methods of evangelism may vary, and "the classes of people you meet with decide for you the way in which the work should be handled” (White, 2002, p. 106).

\section{Conclusion}

In conclusion to this chapter, there are fundamental lessons in the Bible that can be applied today on how to evangelize in the face of a new worldview. The Scripture shows us how the newborn Christian church faced a situation in which it had to include 
the Gentile people-who had a totally different worldview. And since the church was grounded on the word of God, we see also how it was done without compromising the purity and sanctity of the "traditional” church.

The members of the early church were trained by their leaders to do the will of God, which is to reach people, teach them, and save them for His kingdom. Likewise, we need to systematically understand both the group we are inserted in and the ones we are not succeeding in bringing to Jesus, so that plans may be devised to reach them with the precious message of the Gospel.

But there is no instruction in the Bible that people should worship separately, based on their style, social status or anything else, unless it occurred naturally on a given region or intentionally for an evangelistic approach to the local community, being missional churches.

And the different churches must have a real, live connection between them so that they do not lose the focus of being the same body, doing the same business together, each fishing different kinds of fish. They are all fishers of men, fishing from inside the same boat, but using different baits. People converted in such churches will never label the other churches because they are different and they will not be afraid of visiting each other church. They are all brothers and sisters in Christ, living as the Remnant church (Rev 12:17), proclaiming the three-angels message to the whole world, without any distinction of worldview or social status (Rev 14:6-12). 


\section{CHAPTER 3}

\section{LITERATURE REVIEW}

\section{Growing With a Gap}

While the Seventh-day Adventist Church continues to grow in numbers, there still are some groups of people who are very resistant to the Christian message and who are not attracted to it (Gonçalves, 2006, p. 38; 2009, p. 16). These groups are identified in large part with the so-called postmodern society—people with a characteristic worldview that is still being studied and needs a more precise definition (Gonçalves, 2009; Araújo, 2009, p. 581). It is difficult to define it because it is still gaining form; we are experiencing a transition in the dominant worldview of our era, and nobody knows the exact direction of this current social condition (Lyotard, 1984; Gonçalves, 2005, 2009).

While some researchers label all contemporary secular or unchurched people broadly as postmoderns (Tavares, 2009), other specialists understand these as different terms that should not be used interchangeably (Gonçalves, 2009; Pujic, 2006; Lima, 2010). Some authors even avoid the term postmodern when referring to this social condition, preferring to use phrases such as “secular West” or "liquid modernity” (Bauman, 2007; Henning, 2010).

But no matter how we name these groups, their numbers are growing everywhere, and so is their absence in the church. In this work, I will be focusing on doing evangelism to the unchurched people of the downtown Curitiba, especially the young middle class 
community as well as college and graduate students, considering them mostly as postmodern people.

\section{Traditional Methods: No Longer Effective}

One of the problems discussed when it comes to evangelism today is the fact that the traditional approach being practiced by the church does not reach secular people who share the contemporary and postmodern worldview. This is a big challenge not only to the Adventist Church, but to all other churches as well (Schieber \& Olson, 1999, pp. 3536).

Despite the fact that this worldview is more evident in so-called Western cultures (i.e., North America, Europe, Australia), it is also impacting other countries, such as Brazil. The Brazilian weekly periodical Época issued an article on how evangelical churches are trying to adapt to the Brazilian contemporary times in order to reach people who are more difficult today. It evaluates the situation by saying that the evangelical church in Brazil is passing through a "period of transition" in which "the rites, doctrines, traditions, dogmas, jargons and hierarchies are under a deep process of revision” (Alexandre, 2010, pp. 86, 88).

To make things sound different, the worship services are being called "meetings" or "celebrations"; the word "evangelical” is being replaced by "Christian"; and the sermon is said to be a speech or lecture. One of the leading evangelical pastors is quoted giving his opinion on the necessity of change: “The theological seminaries are [still] graduating pastors to a rural Brazil...There are lots of serious people, of course, saying biblical truth, but they are stuck in an outdated format” (Alexandre, 2010). 
As a matter of fact, the contemporary world is becoming more urbanized each year, practically inverting its former “demographic picture” (Lidório, 2008, p. 59; Dias, 2005, p. 278). According to the Brazilian Institute of Geography and Statistics (IBGE), "in 2006 [Brazil] had 81\% of its population [living] in urban centers and 19\% in the rural context. In 2010, according to the same IBGE, the numbers were respectively $84 \%$ and 15\%. Thus, according to this article, evangelical seminaries in Brazil were slow to notice the necessity of change.

Adventist administrators and scholars also recognize this as a problem for the Seventh-day Adventist Church in Brazil. Guimarães (2010, pp. 20-21), for example, suggests that Adventist pastors in Brazil are being trained based on models that were effective when most people lived in rural areas. Accordingly, Tavares (2009) affirms, "the majority of current church practices [in Brazil today] are cultural accommodations to a society that no longer exists” (p. 50).

\section{Fishers, Baits, and Different Kinds of Fish}

Given the situation of churches using traditional and inappropriate approaches that do not appeal to the current generation, and the fact that Jesus invites Christians to be "fishers of men," there must be a general agreement that the "hook is not properly baited" according to the characteristics of the target audience (White, 2002, pp. 106, 556). Since being fishers of people is the mission of the church, evangelism must be planned in accordance to the kind of people who are going to be reached so that the appropriate "bait” or method might be used (Bovon, 2002, p. 171; Marshall, 1992; Nolland, 1989; Wuellner, 1967). Therefore, the first thing to do is to understand the worldview and the profile of the community we want to lead to Jesus. 


\section{Defining the Postmodern "Worldview"}

As mentioned before, several writers admit that it is difficult to define the postmodern worldview because it is still gaining form. What is evident is that this worldview is a reaction to disillusionment and frustration accumulated for many generations because of the failure of the previous era (the modern era) to solve all the

problems of humanity through reason and science, as had been promised (H. White, 2006, pp. 37, 45-56; Paulien, 2008, p. 51). As this social condition is a reaction against what was tried in the past (Norman, 2007), to understand it better, we must analyze the characteristics of the two eras that precede it.

It is good to remember that, generally, there is no particular event or precise date to mark the beginning or end of an era because opinions vary depending on the historian (Bruinsma, 2005). But it is necessary to identify respective periods so that we can compare and contrast their main characteristics.

This is the purpose of the table below, which presents the three main philosophical worldviews in history since the Middle Ages. As we will notice, the postmodern worldview is actually a lack of any vision! Their main problem is regarding the truth. 
Table 1

Philosophical Worldviews in Christian History Since the Middle Ages

\begin{tabular}{|c|c|c|c|}
\hline & $\begin{array}{l}\text { Premodern Era } \\
\text { (c. } 500 \text { to 1700) }\end{array}$ & $\begin{array}{c}\text { Modern Era } \\
\text { (c. 1700-1970s) }\end{array}$ & $\begin{array}{l}\text { Postmodern Era } \\
\text { (1970s to today) }\end{array}$ \\
\hline Center & God and the church & Human reason & None \\
\hline $\begin{array}{l}\text { Truth and } \\
\text { Cosmovision }\end{array}$ & $\begin{array}{l}\text { Medieval Christian } \\
\text { cosmovision, } \\
\text { centered in God but } \\
\text { through the tradition } \\
\text { of the church }\end{array}$ & $\begin{array}{l}\text { Confidence in } \\
\text { human logic in } \\
\text { order to discover } \\
\text { the truth through } \\
\text { the senses and the } \\
\text { laboratory }\end{array}$ & $\begin{array}{l}\text { Pluralistic vision of } \\
\text { culture and religion; } \\
\text { they can accept } \\
\text { conflicting truths } \\
\text { and beliefs }\end{array}$ \\
\hline Source of Truth & $\begin{array}{c}\text { The church } \\
\text { (the Bible was not } \\
\text { available to most of } \\
\text { the population) }\end{array}$ & $\begin{array}{l}\text { Human reason, } \\
\text { science and logic }\end{array}$ & Personal experience \\
\hline Communication & $\begin{array}{l}\text { Manuscripts and } \\
\text { oral communication }\end{array}$ & $\begin{array}{l}\text { The invention of } \\
\text { the printing press } \\
\text { transforms } \\
\text { communication }\end{array}$ & $\begin{array}{l}\text { Internet and media } \\
\text { speed up a } \\
\text { revolution in global } \\
\text { communication }\end{array}$ \\
\hline $\begin{array}{l}\text { Source of } \\
\text { Authority }\end{array}$ & $\begin{array}{c}\text { The church and the } \\
\text { priests (who, as } \\
\text { people believed, } \\
\text { were teaching } \\
\text { according to the } \\
\text { Bible) }\end{array}$ & $\begin{array}{l}\text { Reason, science, } \\
\text { and logic; for } \\
\text { Christians of this } \\
\text { period, who had } \\
\text { the Bible available, } \\
\text { the authority was } \\
\text { in its rationale } \\
\text { interpretation }\end{array}$ & $\begin{array}{l}\text { Distrust of any } \\
\text { authority; consider } \\
\text { the Bible only one } \\
\text { among many other } \\
\text { religious writings; } \\
\text { to postmodern } \\
\text { Christians, each } \\
\text { person can interpret } \\
\text { the Bible as it fits } \\
\text { best for him/her }\end{array}$ \\
\hline
\end{tabular}

Note. Extracted and adapted from http://missaoposmoderna.com.br/deus-na-posmodernidade.

\section{The Premodern Era: God and the Church at the Center}

The philosophical era known as premodern corresponds to the period of the Middle Ages and the Renaissance. During this period, the Roman Church and its priests were the source of all authority and truth. People who lived at this time-mostly rural 
peasants without education—saw God and religion as the center of anything that might happen.

In this environment with little scientific knowledge or any notion of the principles of hygiene and health, when a disease could decimate whole populations, it was considered a supernatural manifestation with a divine or satanic original source. Nobody questioned anything, much less the authority of the church. This was the only way of life that a great part of the world knew.

As a consequence, there was not much progress in knowledge during this period. It was not important to know anything beyond what was necessary to plant, harvest, and avoid being excommunicated from the church, which was a great tragedy in those times. If a curious researcher discovered anything contrary to the "truths" of the church, this person could be punished as a heretic.

That is what happened to Giordano Bruno in 1600, when he suggested, among other things, that the Earth spins around the Sun (and not the Sun around the Earth, as the ecclesiastical leaders believed). For this reason, he was burned at the stake. For presenting the same idea and others, Galileo Galilei was condemned by the church to stay under house arrest for the rest of his life, where he died in January of 1642.

But Isaac Newton—who was born in December of the same year when Galileo died — received a more positive reception when he dealt with the same issues. There was in the air a desire for knowledge. This feeling had been building since the $14^{\text {th }}$ century, manifested in the arts and architecture through such personalities as Dante Alighieri, Michelangelo, and Leonardo da Vinci, among others. 
During the Renaissance, the arts and new discoveries-accepted or not by the Roman Church-awakened humanity to the power of their reasoning and to the oppression they were suffering from religion. This period marked the last part of the Middle Ages and prepared the way for a new era with a new philosophy of life, which we call the modern era, or the "era of reason."

\section{The Modern Era: Human Reason at the Center}

The invention of the printing press by Gutenberg; the 95 theses of Martin Luther against the deceptions of the Roman Church; the translation of the Bible into German (also by Luther); the revelations of Copernicus, Galileo, and Newton; and the exploration of a "new world" — the freshly discovered American continent—among other numerous findings and manifestations, emphasized the necessity of growth and change through knowledge. The phrase “I think, therefore I am,” expressed in 1637 by the philosopher René Descartes, reflects the strong idea that people should use their reason, logic, and rationality. This thought would be the foundation of the era that was to be born. Consequently, Descartes is considered to have laid the philosophical groundwork for the modern era (Grenz, 1997, pp. 17-18).

In view of the importance of using intellect, reasoning, and logic, a great intellectual, cultural, and philosophical movement occurred in Europe in which discoveries and new ideas were exalted through the reflections of great philosophers and scientists. This movement, which happened mainly in the $18^{\text {th }}$ century (the "century of the lights”), was called the Enlightenment, implying that the world was coming out of the darkness of ignorance common in the Middle Ages and being illuminated by knowledge and reasoning. 
The culmination of this period was the French Revolution (1789-1798), which had a great impact and influence on the way people would see the world, reality, and religion for the next two centuries. Due to this, the French Revolution is recognized by some writers as the moment when the modern era began (Zukowski, 2014, p. 108; Grenz, 1999, p. 17).

In the worldview of people who lived in this time period, the great expectation was that the world would become much better with the development of reasoning and personal effort (White, 2006). The discovery of vaccines, for example, would prevent devastating plagues like the bubonic plague. During this time, scientists, scholars, physicians, engineers, and lawyers were overvalued and respected as the creators of saving solutions for our world. Because of their reasoning, there would be no more diseases, disagreement, or poverty; life would be facilitated by knowledge, which would bring peace, prosperity, and long life. The motto of this period was given in 1784 by Immanuel Kant: “dare to know” (Groothuis, 2000, p. 35).

One piece of evidence that science would help humanity was the Industrial Revolution (1760-1830). During this time, incredible machines were invented, such as the great steam looms, which added to the mechanization of production systems, and the locomotive, which facilitated long-distance transport. It was thought that people's efforts to create and invent new things that could improve life would turn the world into a perfect place.

Now, in those times, religion and God were no longer considered necessary. As the planet Earth was no longer considered the center of the universe, God was no longer the center of everything. Men took this place, and religion was considered a throwback of 
knowledge. This thought made Thomas Paine write in 1794, "My mind is my own church” (p. 3), and Nietzsche wrote in 1844, "Religion is the opium of the people." Some decades later, he affirmed, "God is dead.”

As a result of the oppressing attitude of the medieval church, humanity fought to be free from it and from the god it portrayed. In its place, they tried to meet all their needs with logic and reason. After only two centuries of this kind of thought, people's hearts became empty, without any hope or direction. This opened the doors for a new social condition, which we call postmodernism.

\section{Postmodern Era: Nothing at the Center}

Despite all the promises and expectations of the previous era (modern), the world suffered two world wars, the Holocaust, atomic bomb threats, and diseases for which no cure has been discovered. Furthermore, organizations, obviously including the church, began to be seen as manipulators of people who used to force the masses to accept their "truths" to the detriment of other people who had different "truths” (H. White, 2006, p. $56)$.

Also, with the advancement of communications technology and world travels, people have become more conscious of different cultures where the "truth" seems to have different shades of standards and morals. All this order of things has brought about distrust in science and institutions as well as a notion that the "truth" and even the morals are subjective and they depend on the time, circumstances, context, and local culture.

Since the postmodern condition is a reaction against the previous era, people with the postmodern worldview have developed some interesting characteristics. Some of these characteristics are big challenges for the church—mainly for the Adventist church, 
as we are going to see-while others are opportunities for the church to include them effectively in the evangelistic efforts.

\section{Main Characteristics of Postmoderns and \\ Respective Difficulties for the Church}

\section{Negation of Absolute Truth}

Among all the characteristics of postmoderns, the most remarkable is their tendency to believe that truth is "completely subjective; it is within the realm of opinion" (Hahn \& Verhaagen, 1998, p. 16). At the same time, some researchers have noticed that postmoderns actually do believe in absolute truth, but not "in our ability on it" (Smith, 2005, p. 15); thus, "what they tend to reject is not absolute truth, but absolute knowledge" (McLaren, 2000). Or, in Pujic’s (2006, p. 4) words, “They do not reject truth, they just are not sure where to find it or that the Bible contains it.”

This is a natural reaction in response to the manipulations suffered by humanity because of "truths" that could not be rejected by those who were not in the power (White, 2006, p. 56). This specific characteristic is one of the biggest challenges for the Adventist Church when trying to evangelize these people with the message that there is one remnant church that contains the "truth," against all others that contain "parts of truth" or even “misguided truths.” Characteristic phrases such as “when I came to the truth” or “God still has people in ‘Babylon’ [other churches] who we must call to leave it!,” which we are used to hear as jargons in the Seventh-day Adventist Church pulpits are totally negative and unacceptable to the postmodern ear (Paulien, 2008).

The difficulty here even worsens when we consider that, as theorizes George Knight (2008), if the Seventh-day Adventist Church abandons its characteristic "holy arrogance” (affirming itself to be the unique church proclaiming the original biblical 
truth) it may lose its identity as a biblical prophetic movement and its sense of mission as well.

\section{Distrust of Institutions}

Because of the many organized institutions in the past that forced people to conform to their standards and oppressed them, postmodern people shrink from being part of any institutions (Gosnell, 2005, pp. 108, 110; Lima, 2010). Of course, this is another challenge for the church, which has a big organized institution with a set of doctrines and practices that are not supposed to be overlooked or transgressed by its members.

Further, because of the characteristic postmodern position about truth, the problem is only aggravated when such institution representing the church claims to be the “only true one” (Schieber \& Olson, 1999, pp. 35-36; Veith, 1994, pp. 195-196). Here again comes the "problem” of the Adventist "holy arrogance," supposedly necessary to keep its prophetic identity and mission (Knight, 2008).

One evangelical pastor, pioneering churches for postmoderns in Brazil, analyzes the situation: "Everybody knows that spirituality is a good thing as education is as well, but the ones who have been delivering these things are under suspicion for their lack of credibility” (Alexandre, 2010, p. 87). The solution then suggested by this new category of evangelical pastors is to "strip away as much as possible the Christian teachings of all the institutional apparatus” in order to go back to the core of the Gospel which is Jesus and what He does for people.

Despite the fact that we Adventists believe we have a distinctive identity and message as a prophetic movement with a specific mission for the end times, it is time for 
us to preach the core of our message in order to reach postmoderns. The core of the message is about the “everlasting Gospel” proclaimed by the three angels of Revelation 14, reminding the world that there is a Creator and Savior, who designed a happy and meaningful purpose for human life, and there will be a judgment for those who mess it up. And we must communicate it not as an institution, but as human beings who live the message we believe in and who are made better by it.

It is time to go back to the beginnings of the Christian church, when "the way" was not themselves, not their buildings, but their message (Acts 9:2, 19:9, 19:23, 22:4, 24:22). They demonstrated the "way" of the Gospel powerfully because they were not seen as a building or an organization, but as people with a purpose and a mission: spreading the word of God in heavenly power. Since postmoderns feel a great need for belonging, they may join the church if they see it as a community of people who care about life and the best for each other, who have a solid and relevant truth to be lived today, and who have a concrete hope for the future.

\section{Sense of Community and Equality}

As a result of the many discriminations and prejudices that have marked the history of the world, postmodern people are more sensitive to injustices and prejudices against "minorities." Since they believe everybody must be respected in their particularities as long as they are not damaging anything or anyone, they appreciate any movement that serves the community and the underprivileged. They want to belong to a community where they are appreciated and where they can serve even other communities, no matter how they live or believe, since they are helping others as well. 
Coming from generations of families that have struggled to preserve relationships, and having watched their parents marry and remarry but still fail to be happy, postmodern people try to connect to others in search of real intimacy, but fear it at the same time (Paulien, 2008, p. 60). Therefore, postmodern culture gives important weight to relationships. "For them, togetherness is a rare, precious and elusive experience” (McLaren, 2000, pp. 164-165). This must be kept in mind by all who want to disciple them (Hahn \& Verhaagen, 1998, p. 21).

If the members of the church live the real power of the Gospel, loving each other and trying to take care of the needs of others, they will have a better chance to find sympathy from these people, which might be the beginning of a long journey towards friendship and discipleship.

\section{Experience Before Reason}

Because of the frustrations of the era of reason and logic, which promised to be the solution to the problems of humanity, postmodern people want to experience rather than understand something. "People today want more than an intellectual approach to worship. They have greater needs experientially. In other words, worship needs to be an experience. People need to 'feel' the love of God” (Hunter, 2000, p. 135; Gonçalves, 2006, p. 39; Dorneles, 2006). This is probably the reason for the exponential increase of Pentecostalism in Brazil over the last decades.

Postmodern-friendly evangelical churches explore this need for experience by evoking emotion through music, through manifestations of the supernatural, and by praying or shouting in ecstasy. Since the Seventh-day Adventist Church in Brazil has an emphasis on the "reasonable service" (Rom 12:1) very similar to the "contemporary 
white Adventist service” in North America—without much “display of emotion” (Bull \& Lockhart, 2007, p. 221)—this kind of worship is generally not well-received in Brazil. Therefore, in a sensitive Adventist Church, the preacher must instead invite the audience to look for a real experience with God on a day-to-day basis. Thus, a "real experience" with God must be the church's goal, repeated constantly from the pulpit and in the training meetings, which is perfectly acceptable and desirable to postmodern visitors and to all traditional members as well.

\section{Particular Characteristics of Postmoderns in Brazil}

Unlike in North American culture, where the postmodern worldview is present in practically all segments of society, postmodern people in Brazil are mostly—but not exclusively—found specially in three groups today: (a) wealthy people—not necessarily rich, but wealthier than the average, with conditions to enjoy high class circles and traveling abroad as well; (b) the academically educated; and (c) a growing number of teenagers and youth, as the mass media clearly promotes and grows this worldview in their minds (Paulien, 2008, p. 11; Gonçalves, 2006, pp. 44-45).

Curiously, as much of the worldview in Brazil follows that of North America because of the electronic media, it seems evident that this same configuration used to be true in North America back in the 90s, before invading all other social classes of today. As an example, when Paulien (1993, p. 161) defines the postmodern people in America in 1993, he includes the first two groups of the three just mentioned above, calling them "educated" and "white-collar secular people."

One example of the correlation of the three groups mentioned above and the postmodern worldview in Brazil is found in the Brazilian periodical Revista Adventista 
(“Adventist Review"). It presents the work of two chaplains at the Adventist Hospital in the state of Pará (North of Brazil) who are using a postmodern approach to reach highsociety people (“Curar o Corpo,” 2012). In this article, it is evident that they are using the term postmodern to make reference to wealthy and educated people. These chaplains' good results are shown in their number of baptisms: 33 people in less than two yearswhich is impressive in Brazil, not because of the numbers, but because of the social level of the people baptized: judges, physicians, lawyers, students of medicine, etc.

Another example of the church appealing to what is classified as "postmodern" people in Brazil is found on the same page of that periodical, where it is stated that the Youth Department of the church in Brazil had then just launched a new Bible study series called "O Resgate da Verdade" (Borges, Reis, Assis, \& Cardoso, 2012) or, "The Rescue of the Truth”. It is advertised as “designed for postmodern people" and as a "biblical study series for college students” (“Estudo Bíblico,” 2012). Here the young college students are clearly identified as postmoderns.

Ricardo Mariano, a sociologist, "one of the biggest researchers of the evangelical phenomenon in Brazil," also makes this connection when he explains the new approach of the evangelical churches: "The goal is the search for a certain intellectual elite, a better informed public, collegiate, more educated than the people who fill the popular churches" (Alexandre, 2010, p. 90).

It is important to reaffirm here that the postmodern demographics and configuration in relation to church attendance in Brazil are totally different from what literature has been showing in North America. The Seventh-day Adventist church has experienced a serious shortage of members in North America: "almost half of white 
North American Seventh-day Adventist members are 60 years of age or older” (Sahlin \& Richardson, 2008).

On the other hand, $50 \%$ of the Adventist church members in South America are less than 35 years old and 20\% of the total are less than 17 years old (Kohler, 2012, p. 6). In this sense, as mentioned in the previous chapter, the Brazilian youth and young adults are not yet as secularized as their respective American age groups are, but as the postmodern worldview is growing in Brazil, those people are becoming increasingly more resistant to the church as well

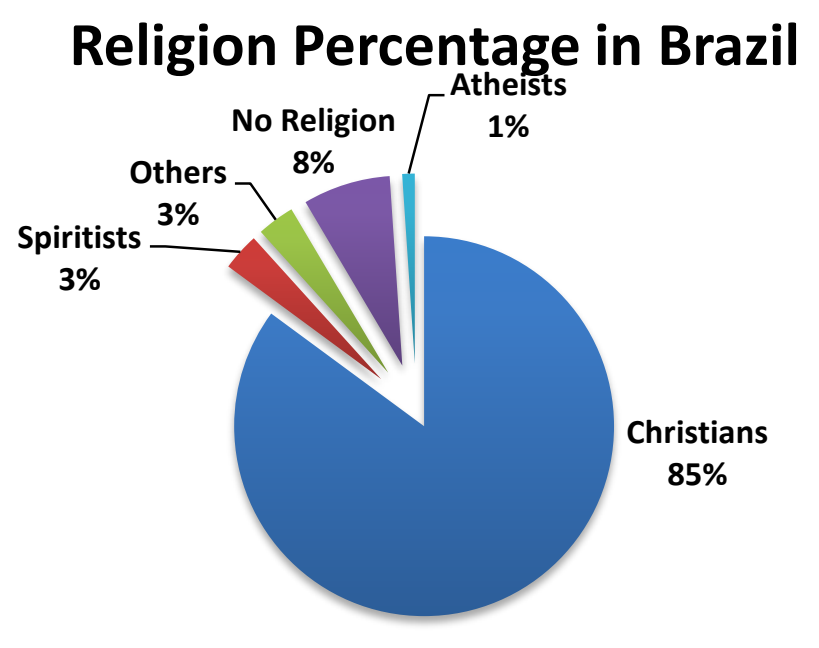

Figure 1. Religion proportions in Brazil's population in 2013. Data from Datafolha Poll. Retrieved from http://media.folha.uol.com.br/datafolha/2013/07/22/religiao.pdf

This graphic is based on a 2013 poll by Datafolha, one of Brazil’s main polling institute, performed in 180 Brazilian cities, with 3,758 people (Datafolha, 2013). It shows that $85 \%$ of the 200 million people in Brazil are considered Christians. Catholics are the great majority, at $67 \%$ of Christians (or $57 \%$ of the population). The other $33 \%$ of the 
Christian group is constituted of $22 \%$ Pentecostals and $11 \%$ non-Pentecostals (respectively $19 \%$ and $9 \%$ of the total population).

These numbers have shown a gradual decline of the Catholic Church and a correspondent growth of evangelical churches, mainly Pentecostal ones. In 1994 Catholics were $75 \%$ of the adult population in the country, compared to only $57 \%$ now, while evangelicals are estimated to rise to 50\% by the year 2020 (Alexandre, 2010). Despite these numbers, fewer people are actually committed to their professed religions to the point of going to church every week or more. According to the chart below in Table 2, which shows data from the same 2013 Datafolha poll, only 17\% of Catholics go to church more than once a week (against 63\% of Pentecostals), and $28 \%$ go once a week. Curiously the 3\% Spiritists (Kardecists) were included in this chart among Christians.

This table shows us that, in spite of the growing numbers of evangelicals, church is not being considered so relevant or interesting as to be visited with more frequency than the politically correct. If this poll is compared to other polls in the past, it is also possible to see a gradual distrust and abandonment of religion, as the numbers of atheists and "other religions" have grown together. 
Table 2

Percentage of Religious Attendance in Brazil in 2007 and 2013

\begin{tabular}{|c|c|c|c|c|c|c|c|c|c|c|}
\hline & \multicolumn{2}{|c|}{ All } & \multicolumn{2}{c|}{ Catholics } & \multicolumn{2}{c|}{ Pentecostals } & \multicolumn{2}{c|}{$\begin{array}{c}\text { Not } \\
\text { Pentecostals }\end{array}$} & \multicolumn{2}{c|}{ Spiritists } \\
\cline { 2 - 11 } & $\mathbf{2 0 0 7}$ & $\mathbf{2 0 1 3}$ & $\mathbf{2 0 0 7}$ & $\mathbf{2 0 1 3}$ & $\mathbf{2 0 0 7}$ & $\mathbf{2 0 1 3}$ & $\mathbf{2 0 0 7}$ & $\mathbf{2 0 1 3}$ & $\mathbf{2 0 0 7}$ & $\mathbf{2 0 1 3}$ \\
\hline $\begin{array}{c}\text { Go to } \\
\text { Church }\end{array}$ & $\mathbf{9 0}$ & $\mathbf{9 5}$ & $\mathbf{9 4}$ & $\mathbf{9 3}$ & $\mathbf{9 8}$ & $\mathbf{9 8}$ & $\mathbf{9 9}$ & $\mathbf{9 8}$ & $\mathbf{9 5}$ & $\mathbf{9 0}$ \\
\hline $\begin{array}{c}\text { Go more than } \\
\text { once a week }\end{array}$ & 26 & 31 & 16 & 17 & 60 & 63 & 50 & 51 & 29 & 23 \\
\hline $\begin{array}{c}\text { Go once a } \\
\text { week }\end{array}$ & 30 & 27 & 35 & 28 & 25 & 22 & 26 & 30 & 30 & 24 \\
\hline $\begin{array}{c}\text { Go once } \\
\text { every other } \\
\text { week }\end{array}$ & 9 & 9 & 10 & 11 & 6 & 5 & 6 & 5 & 12 & 10 \\
\hline $\begin{array}{c}\text { Go once } \\
\text { every month }\end{array}$ & 14 & 16 & 18 & 21 & 4 & 5 & 14 & 7 & 14 & 22 \\
\hline $\begin{array}{c}\text { Go once } \\
\text { every 6 } \\
\text { months }\end{array}$ & 5 & 5 & 6 & 6 & 2 & 1 & 2 & 3 & 7 & 7 \\
\hline $\begin{array}{c}\text { Go once a } \\
\text { year }\end{array}$ & 4 & 5 & 5 & 7 & 1 & 1 & 1 & 1 & 3 & 3 \\
\hline $\begin{array}{c}\text { Go less than } \\
\text { once a year }\end{array}$ & 2 & 3 & 3 & 3 & 0 & 1 & 1 & 2 & 0 & 1 \\
\hline $\begin{array}{c}\text { Do not go to } \\
\text { church }\end{array}$ & $\mathbf{1 0}$ & $\mathbf{5}$ & $\mathbf{6}$ & $\mathbf{7}$ & $\mathbf{2}$ & $\mathbf{2}$ & $\mathbf{1}$ & $\mathbf{2}$ & $\mathbf{5}$ & $\mathbf{1 0}$ \\
\hline
\end{tabular}

Datafolha Poll, http://media.folha.uol.com.br/datafolha/2013/07/22/religiao.pdf

However, Christian culture is still very influential in Brazil. Even people who rarely go to church on occasions other than Christmas, weddings, or funerals (who would be considered “unchurched” or "secular” for Adventists or evangelicals) most often consider themselves as religious Catholic people who believe in God, the Bible, and a judgment. According to Agreste (2007) in his book Igreja? Tô Fora! (“Church? I’m Out!”), and to Kimball in “Eles gostam de Jesus mas não da igreja” (“They like Jesus but not the church"), they just think the church is irrelevant or "boring” (p. 12). One interesting fact is that practically everybody "knows” Jesus in Brazil. Therefore, the 
challenge for Christian churches over there today is not exactly to inform secular postmodern people about who Jesus is in order to Christianize them, but to help them to have a relationship with Him, loving and following Him, eventually becoming effective members of His church and its mission.

\section{Adapting the Church or Planting Postmodern-Friendly Ones?}

Based on the known difficulty in reaching postmodern people, there is some disagreement among scholars and leaders on whether the church's style of worship and evangelism should be changed to make it friendlier. If the answer is yes, the question is how to do it without compromising the church's mission and purity (Canale, 2010) and without causing scandal to faithful traditional members.

Some leaders argue that the worldviews of Christians can also change (as $\mathrm{H}$. White, 2006, p. 160) and therefore they are in favor of a radical adaptation to the current culture. According to Hahn and Verhaagen (1998, p. 195), for example, this adaptation would happen if the leaders worked toward "reflective deliberation and creativity" in order to preserve the commitment of the church while including the postmodern mind.

Other leaders fear that this adaptation or accommodation may be dangerous for the church. "Many examples of faulty adjustments demonstrate that accommodation has been more a compromise of the faith than an adaptation to the culture” (McGavran, 1974, pp. 42-52; Dorneles, 2006; White, 2010, p. 570). Thus, while one side proposes contextualization of the message to make it relevant and meaningful to postmoderns, there is, on the other side of the controversy, a real concern that the exaggeration of the contextualization would generate syncretism instead (Bauer, 2005; Ng, 2005). 
But what both parties agree on is that the postmodern mind is so desperate to flee from the impositions, manipulations, misconceptions, and injustices of the previous era that these people eventually become empty spiritually, and therefore they really need to be helped (Dorneles, 2006; Bast, 1991; Oliver, 2006). The church must do something to reach them - as well as all the others - in order to fulfill its mission.

\section{Adapting the Already Existing Church}

According to Schieber (1999), “the church can adapt because the church’s message has an unchanging focus: the gospel of Jesus Christ” (p. 11). However, it is not necessary to adapt to the point of suddenly removing old traditions, since this would cause difficulties for older faithful members. There are traditional practices in some churches that older members do not even consider the possibility of changing. For example, the so-called "platform" (that formation of four or five people seated behind the preacher) is one element of Adventist services that we have no reason to keep beyond the fact that we are used to it (and have been since the 1800s). Some people cannot imagine the sermon being delivered without those people seated behind the preacher, or without the wooden pulpit, or without the preacher wearing a suit and tie.

However, none of these things—platform, pulpit, suit, or tie—is the main point to adapt for contemporary people. What really needs to be adapted is our attitude toward them. Our language should clearly communicate that our message is relevant and that we care about helping people. Our hymns and sermons should be comprehensible and relevant to speak to the hearts of people who are struggling with their marriages, children's education, drugs, sexual diseases, cancer, unemployment, depression, anxiety, etc. And the source of all hope must be in Jesus and His word. 
The traditional church in Brazil has always focused on evangelism. Thus, it only needs to be updated and adjusted in order to reach and include postmoderns. Pastors should plant this vision in members' hearts by promoting understanding of the postmodern mindset through special lectures and seminars (Bruinsma, 2014; Gardino, 2014). The church may learn little by little how to change, not its "style," but its approach and performance to communicate the Gospel in intelligible and powerful language. Members will be surprised to learn that changes in the church's style are less necessary than changes in themselves, the people representing the church. If we really love the lost, we will change ourselves and our approach in order to gain them as sincere friends and then bring them to Jesus.

If a pastor wants to train a traditional church to include postmoderns from the neighborhood, the "relational approach" is certainly the way to go. But first he must prepare his church to become (a) a family-like place, with a communion that involves everyone (Kimball, p. 228), and (b) a small-groups-based church, which is much less threatening for people than going straight to the church, and where people interact with each other, growing their communion among themselves and with God (Gladen, 2011, p. 96; Beckham, 1995).

\section{The Family Model Church}

The "relational approach,” "friendship evangelism,” or "incarnational method," which are all based on similar ideas, are the most emphasized approaches in the current literature for connecting postmodern people to the church (Tavares, 2009; Pujic, 2003). This strategy is about reaching people in their common day-to-day lives creating positive and relevant relationships, generating confidence and trust. But this is the environment 
expected in the church as well, "where people can feel at home and accepted” (Bruinsma, 2011, p. 2492).

The idea of a family worshiping together is taught in many books as a model for church worship and life (Huttenlocker, 1986; Hellerman, 2001). Some of them compare the worship time in the church to the worship time at home, when all the family gathers together in communion with each other and with God (Cosgrove \& Hatfield, 1994). If the church sees itself as a family where people love and respect each other naturally, it will always have people of every social level feel more comfortable and opened to our message (Rode \& Rode, 2007, p. 72).

\section{Special Programs Performed by Special Ministries}

Another idea is to keep the different mindsets grouped together in church through activities on occasions other than Sabbath morning worship. This can be done through specific programs in the church that address their different needs and concerns in day-today life (Bruinsma, 2014, p. 1950). Such programs would be performed by special ministries of the local church, made up of volunteers who would identify themselves with those ministries and participate cheerfully.

Examples of such programs are abundant: a conference for professionals, a meeting to deal with issues about parenthood, a meeting on health, a meeting of psychologists, a symposium on education and service to the community, etc.

These meetings are important because they will deal specifically with issues related to the different mindsets. The church members will not only come to meet their friends who share their same interests, but also to bring others who are not converted yet. These visitors will see how effective the community of believers is in serving its 
members and the community (Norman, 2007). I believe such events are a great strategy

for evangelism in big cities in Brazil, as it is already happening in many Seventh-day

Adventist churches in the South of Brazil.

\section{Small Groups as "Subcultures \\ Within the Church"}

Some church leaders may be very resistant to changing their methods even when their old way of doing things might not be working (Bruinsma, 2014, p. 2406). As

Paulien (1993, p. 204) observes, "there are churches where the corporate personality is such that it cannot work effectively with secular people. In such cases, those who carry a burden for lost secular people need to form a subculture within the church.” Then he explains the idea of "subculture within the church" in the following terms:

"A subculture is a setting in which a particular class of people who belong to the church or are interested in the church but don't quite fit socially or politically can get the spiritual uplift they need. It's a halfway house, if you wish. A subculture aimed at the secular mind-set would intentionally avoid the minor irritations that drive secular people away from churches. Such a subculture can take many forms. It could be a Sabbath school class, a prayer group, a home Bible-study group, or even a social club.” (Paulien,1993, p. 204)

According to Burrill (1998), the small group is an effective entry to the church in this present era: "In this biblical twenty-first century Adventist church, people would join the church through a small group" (p. 227). Burrill calls this model "the church of the future," where people would enter the church through relationships in the small group. Coming to the idea of the church as the "wineskin," he proposes the transformation of the church into new wineskins, mostly based on small groups:

We must pour most of our energy into establishing new wineskins. Sometimes the new wineskins will need to be developed within the existing church. In other words, instead of eliminating the old way of doing things, add the small group cell structure alongside the existing structure. Eventually this "new wine" will take hold and become the whole, while the "old wine" slowly dies. But if we should seek to 
completely eliminate the old in order to create the new, Jesus indicates that we will destroy both. (Burrill, 1998, pp. 257-258)

Tavares (2009, p. 105) also agrees that "small groups provide multiple points of entry into the church, and offer a very effective form of evangelism.” According to him,

small groups meet the spiritual needs of the church, and through this evangelistic approach members' lives can have meaning and purpose. In small groups members and non-believers can be appreciated, respected, and can have a sense of community enjoying deeper relationships, receiving help, and developing mature faith. (p. 106)

People feel comfortable among people like themselves, with common worldviews, ideas, issues, pleasures, and struggles. Oliveira (2003) recognizes that for the early church "the small groups or the churches in the houses became the crucial strategy in spreading the Christian faith” (p. 12). He cites biblical verses such as Acts 12:12, 15:15, 32-34, 17:5, 18:7, and 21:8. People would meet in houses with some converted people who shared the same social level or worldview, and would grow in their relationship and knowledge of God. After some time, they would be discipled naturally, and the church would grow outside the buildings we call churches.

That is probably why the following well-known quote by Ellen White on this topic can never be overused: "The formation of small companies as a basis of Christian effort has been presented to me by One who cannot err" (White, 1948, Vol. 3, p. 84). She says that "the object of assembling together" is "to edify one another by an interchange of thoughts and feelings, to gather strength and light, and courage by becoming acquainted with one another's hopes and aspirations” (White, 1948, Vol. 2, p. 578).

However, it is important that all small groups get together "under one roof" in the church with a regular frequency in order to keep the idea of being all together one and the same body in Christ (Donahue \& Robinson, 2012; S. Gladen, 2011). 
S. Gladen (p. 96) says he does only two general gatherings of small groups a year in the church. On the other hand, in his "Small Group Guidelines and Agreements" form, every small group member has to check the item "we will do our best to attend the following service together" and then check one of the weekend services options to regularly participate in (www.smallgroups.net/Small-Group-Ministries-DownloadsSmall-Group-Resources.php).

In our Seventh-day Adventist Church context, it is suggested that all small groups should be "encouraged to attend the Sabbath-morning worship service whether or not it feeds them, because the body needs to get together and worship on a regular basis. You need to be there because you are a part of the body” (Paulien, 1993, p. 206).

\section{Planting Postmodern-Friendly Churches}

If the "resistant churches" mentioned above are really difficult to adapt for the inclusion of a postmodern neighborhood, then planting a new church will be the best solution. As mentioned before, based on the parable of "new wineskins for new wine" (Luke 15), some have proposed to build up “new churches” where a "new style” of worship and evangelism can be performed in order to impact contemporaneous people. "Style of worship" means everything involved in the worship services that can be performed differently depending on the culture of the worshipers, such as the kind of music, depth of the sermon, expressions of praise, level of formality, manifestations of emotions, the interaction between people on stage and people on the benches, etc. Some people prefer a very formal way of worship, choosing very old hymns with "King James Version” lyrics, few interactions between the preacher and the attendance, etc. Others prefer contemporaneous songs, participation, interaction, and manifestation of emotions. 
Thus, according to this interpretation for the parable of the wine and wineskin, the new style of worship (informal and interactive) should not be performed into the "old" churches — it would "damage” both the message and the congregation. The "new churches”, in turn, would appropriately accommodate the new generation’s understanding about worship in order to feed them with the message of the Gospel and disciple them.

The problem is that, depending on the level to which such a church wants to accommodate the new paradigm, without proper care and knowledge of the doctrines and principles, it can be even dangerous, eventually turning the church into something else out of its purpose and character (Smith, 2005, pp. 20, 35). Some evangelical churches, for example, include dancing in the worship as an "adaptation.” The argument for this attitude is that "like genuine faith, [dancing] is an intimate experience," which postmodern people appreciate (Raschke, 2004, p. 205; Maberly, 2005). The apparent logic behind this idea is that not dancing in church "may have far more to do with cultural style than biblical teaching” (Raschke, 2004, p. 205).

The goal of those who defend this kind of adaptation is to make the current generation feel comfortable enough in the church to learn about Jesus and then be converted. But this kind of “conversion” must be questioned: what would the person be converted to? To Jesus or to the style of worship itself? To the music? To the technology and media of a "cool” church? Is this person really being discipled to follow a life commitment to Jesus? Is this person aware of the great controversy between Good and Evil and the necessity of trusting in His word and being baptized with the Holy Spirit on a daily basis? 
Therefore, the church must not only adapt to be friendly to postmodern people and all others, but also adhere to Bible-based church principles, with the proper Spirit and the proper simplicity of the Gospel.

Planting a contemporary-friendly church in order to reach postmodern people should be clearly understood by all members as a local missional effort of the church, and not as a polarization of a "different style" of worship. With this concept in mind, much confusion can be avoided. People will then be trained to be able to join this mission as joyful participants.

\section{Experiments in Brazil}

The greatest effort of the Seventh-day Adventist Church in Brazil to address this issue has been the launch of Nova Semente ("New Seed”) Seventh-day Adventist Church, in the great metropolis of São Paulo. Founded in 2005, is an experiment in approaching the postmodern mind which is drawing the attention of Adventist administrators and pastors in Brazil. Few other new Seventh-day Adventist churches are being modeled after it as experiments as well (to-date there are three experiments similar to that one, in three different States of Brazil).

One of these experiments is one already mentioned, in the State of Pará, in the North of the country, which is recognizably based on the style of Nova Semente Seventhday Adventist Church. Since the culture in the North of Brazil is somewhat different from that in São Paulo, the chaplains of the Adventist Hospital in Pará adapted the model to their location and culture profile. As a result, they are winning a good number of their target population to the church—and to a commitment to Jesus through baptism ("Curar o Corpo,” 2012). One of the pastors in this project said that before this approach, the 
results (numbers of baptisms) were "too sporadic," since, according to him, "what was being missed was the right methodology” for that public (“Curar o Corpo,” 2012).

\section{Questionings and Concerns}

As one of the leaders of this pioneering enterprise in Pará recognizes, “any project working with a different methodology may create some questionings.” He believes that only by the "appearing of the fruits” do "people begin to understand” (“Questão de Método,” 2012, p. 28). These questionings are legitimate, as Fernando Canale (2010) points out the fact that many churches are actually "going back to Rome," and that Seventh-day Adventists, with their distinct message, should be the leaders of "an alternative movement” to reach those minds instead of playing "follow the leader" with other current denominations.

Changes always bring questions, since there is the worry that the church principles will also be changed. This danger is real only if the leaders of the projectwho must be carefully chosen by the pastor according to their knowledge of the principles and their faithfulness to them-are not trained properly.

They must understand the purpose of the church. They must always remember that they are one part of the worldwide remnant church performing a local evangelistic strategy. They must keep in mind the teachings of the Seventh-day Adventist Church and its history, foundations, and vision, so that they never lose the Adventist "DNA": the church's love for the law of God and the second coming, its desire to proclaim the three angels’ messages (Rev 14), and its focus, passion, and submission to the Scriptures and to the Spirit of Prophecy. 


\section{Training the Church to Narrow the Gap}

As the literature has shown, the church must be trained to cooperate as much as possible in narrowing the gap between generations and worldviews. The local pastor must make the members of the church aware of both the postmodern mindset and the purpose of the church. After the members have had a reawakening and commitment, they must do what is proper based on that knowledge in order to fulfill the mission of the church.

The chaplains at the Pará Adventist Hospital in Brazil, for example, have a team of 30 members created just for the purpose of reaching people with the new approach. The chaplains "invest six months in training in order to educate the team on the worldly mission of the church, the postmodern profile and the methodology to reach them" (“Questão de Método,” 2012, p. 28).

This training begins with acknowledging the postmodern reality and then the purpose of the church; then people enter into a commitment to be that kind of church that God expects for this time and situation; and finally, the new committed church will work on planning the proper actions.

Knowing

\section{Understanding the Postmodern \\ "Worldview"}

"Evangelization is most effective when it identifies and addresses the concerns, needs and interests of people. The implication is that we need to know the people we are seeking to evangelize” (Bast, 1991, p. 10; Oliveira, 2009, p. 22).

One thing that most Christian authors agree on about postmodern culture is that people's own characteristics can (and must) be used in order to win them to Jesus. For 
example, despite the fact that postmodern people reject religious institutions, they are “deeply curious about God” and they have indeed a spiritual hunger (Hahn \& Verhaagen, 1998, p. 93). According to Gonçalves (2005), "while postmoderns are admittedly not in favor of organized religion, they are not necessarily in opposition to God” (p. 260).

This interesting characteristic should be learned by church leaders and members so that they can intentionally create the conditions for success. The idea is to have postmodern unchurched friends satisfied in their curiosity about God with programs dealing with His character, presence and love.

\section{Understanding the Purpose of the Church}

The idea of changing some practices of the church in order to reach unchurched people may be frightening for traditionally faithful members. But, as already mentioned, this mission demands more changes in the members themselves than in the church. If members are trained first to realize what God expects of the church, it may awaken in them the desire to be that church.

According to Hunter's opinion, “an increased awareness of the nature of Christ’s body — the church—will mean a new understanding for many who were raised in the church and who subtly came to believe that the church is an institution” (Hunter, 2000, p. 75; Oliveira, 2009, pp. 22-23). This will lead to a willingness and disposition to include the unchurched—even if only by being more sympathetic to visitors.

\section{Being}

Beyond receiving acknowledgment of the postmodern situation, the church members must decide themselves to be what God expects of them through real 
conversion. Then, the members of such a church—not the outward appearance of the building or its services—are to be transformed into a "community of belonging" (Gonçalves, 2006, pp. 46-47), which is indeed a "postmodern-sensitive church.”

If the church is seen again as it was in the New Testament—a community of believers instead of a building for the believers—-this very acknowledgment will help in creating discipleship and a sense of community among members and visitors (Park, 2006). Researchers on this area understand "educated, white-collar secular people are not usually looking for the 'true church.' What they are delighted to find is a community that is fully devoted to an open, honest and continuing search for truth” (Paulien, 1993, p. 161). Furthermore, what contemporary people want today is not "dogmas, but ... honesty" (Alexandre, 2010, p. 90).

\section{Doing}

What we preach means nothing if we do not act according to our words. Two characteristics of postmoderns that can work in favor of both the church and themselves is that they have a "concern for those who are marginalized" (Reader, 1997, p. 26) and "they must be active and involved” to feel like they belong (Zoba, 1999, p. 94).

The church can give them important roles in programs that involve taking care of minorities around the church, and by extension taking care of themselves while they are working with the church members. "Worship to them means that everyone is active and involved, not just the 'people on stage or up front”' (Zoba, 1999, p. 94).

Thus, according to Gosnell (2005), “a congregation exhibiting an activist mission orientation ... should be effective in attracting the postmodernist” (p. 105). The church must act in such a way that outsiders see it as a good community through its actions 
(Veith, 1994, p. 211). Therefore, "in the postmodern search for authenticity, the church ought to be a place of real service to others" (Gonçalves, 2006, p. 54). Probably that is the reason why community service is one of the growth factors for urban churches (Sahlin, 199, pp. 74-75).

If the church is trained and made aware of the situation and then it plans a strategy to serve the community, it will not only give a positive impression of the church, but might also attract unchurched postmoderns who are invited by their friends to participate in such activities for the good of the community (Kimball, 230).

\section{Conclusion}

The Seventh-day Adventist Church in the South of Brazil can be educated and trained in order to reach and include people with the postmodern worldview. It is successfully doing this in other regions of the country. If a church is not baptizing postmodern neighbors, it might be just following an old traditional pattern that worked well for previous generations but might appear meaningless to current ones because of the increasing postmodern worldview.

Change begins with the pastor giving information about the situation of the social world around the church and the mission of the church. Then, after commitment from the members, a plan of action must be organized, keeping in mind that the most important change is not so much in the practices of the church, but in ourselves, so that we can have the right approach to deliver the same good old Gospel to this generation.

There is no need to create polarized churches with labels of "postmodern" or "traditional” once the members understand that they must include all kinds of people. However, if the church members do not understand the necessity of some few 
adaptations, a new church must be planted with members who would like to enjoy this missionary journey. The intention of the new church in this case is not to polarize, but to fulfill the mission given by Jesus Christ. 


\section{CHAPTER 4}

\section{INTERVENTION PROCESS}

In this chapter, I describe the intervention process in two phases. The first phase happened in an already existing church: Central Curitiba Church, in Curitiba, the capital of Paraná in southern Brazil. This phase was all about informing, encouraging, and training the church leaders and members on the issue of contemporaneous evangelism, trying to develop in them the desire to adapt their approach to include postmodern people.

After that, I explain the second phase of the project, which was to plant a new church, born out of the first one and cared for by it. The second church is trained and focused on doing mission in such a way that it may be able to include members of the contemporary or postmodern public who would not go to the previous church because of some practices that generally awaken their prejudices. This church is housed today in an auditorium called Espaço Novo Tempo Curitiba (ENTC), five miles away from the first church, in the same city.

\section{Some Background}

City of Curitiba

Curitiba is the capital of the state of Paraná, in the southern region of Brazil. There are 2.8 million inhabitants in the city and 3.4 million in the metropolitan area (in 2014). It is the seventh most populous and the fourth wealthiest city in Brazil (right after 
São Paulo, Rio, and Brasilia). It is called a "model city” because of its urban architectural projects and performance in transport and ecology.

The population includes a mixture of people from many different countries and cultures, mostly European. As a great urban center, Curitiba has many of the so-called "urban tribes" (emos, hipsters, hippies, gothics, etc.) and an increasing number of people being influenced by the postmodern worldview.

\section{Central Curitiba Seventh-day Adventist Church}

Like the city, Central Curitiba Church was planned to be modern and huge. It is an atypical Brazilian Seventh-day Adventist church in its numbers. In 2013, it had over 2,600 members, with 40 elders, 110 deacons, and 110 deaconesses, just to give a few numbers. It is said to be the biggest Seventh-day Adventist church in Latin America apart from the churches in colleges and universities.

Favored for its location in the center of the city, with a beautiful interior design, it has many wealthy and academically educated as well as young adult members. Thus, naturally, many of them already have a desire to make the church friendlier to their secular colleagues. There is a huge LED screen on the front stage so that even those farthest away can see the face of the speaker, the lyrics of the music, and the informal video news that is played between the worship service and Sabbath School (in this order). People speaking on stage are generally quite informal in their communication, trying to be naturally clear and sympathetic to both audiences: those physically present and the sometimes 500 to 1,000 people watching live on the Internet (www.iasdcentral.org.br). Every year they baptize around 100 people through evangelistic programs inside the church. 


\section{First Phase: Awareness of the Situation and Motivation to Act}

In the beginning of the first phase of this project, leaders and church members of the "mother" church must be aware of two situations: (a) the increasing number of people with the postmodern worldview; and (b) how the church is falling short of reaching them for discipleship. After coming to this awareness, they must be motivated to fulfill the purpose of the church, reaching people of every "tribe” and "tongue” through the everlasting Gospel (Rev 14:6). Then, after one year of improving evangelism and putting it into action, there comes the second phase: to plant another church, born with the same profile, but even more prepared for the current generation.

I had the opportunity to be called by the Southern Paraná Conference in order to accomplish this goal as an associate pastor at Central Curitiba Church, in the heart of downtown Curitiba. According to the plans for this project and the agreement with the conference president, one year would be enough to improve the evangelistic efforts of that church while training a core group to plant a new one more focused on including local contemporaneous people.

After I accepted this call, the legal process of moving from Michigan to the south of Brazil took some time, and I arrived in the second half of March, when the yearly calendar of the church was already established and working. However, I found some gaps in the calendar and used them to train the church leaders and members about the postmodern worldview and share the vision of being a more sensitive church and planting a missional daughter church. 


\section{Calculating Limits}

After I was introduced to the church as the new "evangelist pastor,” at my first opportunity, in agreement with the senior pastor, I talked to the main elders to determine how much the church wanted to improve their evangelistic efforts to include a class of society that had barely been touched by our programs.

This first meeting helped me measure the church’s desire to adapt in order to include the postmodern people of the city, and consequently the amount of effort and time that would be spent in this direction. It would also determine how many lectures and what kind of content would be needed to communicate the vision to the church so that they would feel enough passion for it to produce action plans.

In the previous year, the church had begun a plan of working through ministries. Now they were very busy with that and doing a great job because the ministries involved many more members in active voluntary work. They had ministries to visit people in prison (men and women), ministries of healthy cooking, Sabbath School in English, psychological care for addicted people and relatives, etc.

However, in spite of the good movement created among members, there is a limit that generally cannot be crossed in existing churches when doing evangelism. There are some traditional features, like the very formal dress code, the style and lyrics of the music, and some practices and conventions that are strange to unchurched people but cannot be updated without scandalizing many good Adventist believers. It is almost like putting new wine into old wineskins (Mark 2:22).

This is why it is important to plant a new church from that one, with the same purpose of reaching people, with the same 28 biblical beliefs of the Seventh-day 
Adventist Church and the same DNA, but without some of the traditions that make little sense to unchurched postmodern people and that actually create barriers. The Central Church leaders are doing the best inside the limits of an already existing church. During my year with them I learned more things to apply in the yet-to-be-born church where those limits could be overcome.

\section{Preparation}

While helping with the existing Central Curitiba Church ministries (of which there are more than 60 now), I created one more to include “different” people: a twomonth series of worship services in English on Sunday mornings. Beyond Adventist youth, a few people who couldn't speak Portuguese came to these meetings, as did some who had never come to an Seventh-day Adventist church before. These people were always invited to the Sabbath School class in English on the next Saturday. Currently, there is one atheist who has been attending that class for almost two years. Members of that class have told me they believe he is gradually being converted by participating in the Word of God. So do I.

Also, during that year, while giving Bible studies and preaching, I methodically invited leaders and staff members to participate in lectures about the postmodern condition and the Seventh-day Adventist Church. The leaders and official members who identified themselves with this issue came to learn —and many of them became core members of the second church one year later.

Since Brazilians do not like long-term trainings — even when divided into a short series over a few days in a row-they had to happen preferably on Saturdays (before sunset). Seventh-day Adventist members in Brazil generally do not come in significant 
numbers on other days of the week, even on Sundays. Thus, the Saturday afternoons dealt with the following issues:

1. Culture, worldview, and truth

2. The postmodern condition

3. Paul's strategies depending on his audience's worldview

4. Evangelism in the primitive church

5. Ellen White's statements on evangelism in big cities

6. How to make the church services more friendly and relevant

7. Traditions and principles

8. Evangelism as a day-to-day lifestyle

9. Commitment to the project

At the conclusion of the seminar for the leaders, after their acceptance and engagement, I could as well share the vision with the whole church for several Sabbaths from the pulpit.

\section{Sharing the Vision With the Church}

In the second half of the first year, beyond informing people about the postmodern condition and planning strategies, I started to announce more publicly from the pulpit that a new church was going to be planted. It was becoming clear that the new church would have a missional profile, and its challenge would be to include postmodern people, beginning with our own friends that would not go to a conventional church.

The audience was becoming conscious that it would be a daughter church that would need to be cared for in its beginnings. Some active young adults and good leaders were personally invited to be part of the new church, and some were appointed as to-be 
leaders. Others would be chosen in the new building, according to their gifts and dispositions, which would be discovered through tests applied in the first weeks there.

\section{The Sabbath Right Before Moving}

One year after the launch of the program, on the Sabbath right before the opening of the new church, all local members were aware of the plans. I made a public appeal from the pulpit, inviting to the stage all those who felt called to be part of this challenge: to become members of a contemporary missional church supported by the previous one and by the local conference as well.

All those who had been recruited or who had just accepted the call came up to the stage at the conclusion of the sermon to receive a special blessing for success in their new evangelistic efforts. This was important so that they could be seen not only as leaving the church to transfer to another one, but as missionaries sent by the church on a very important mission: evangelism to difficult people. A mother church generally understands and supports its daughter.

Now, I had 39 members who had been recruited and prepared for that mission and 19 more who were added in this last call. Despite the fact that it was only $2.3 \%$ of the whole membership, it was a very good number. Given the size of the church, I intentionally did not promote the task as easy; otherwise there would not be enough space for everybody in the new building. That people who answered the call knew it would be

difficult, as I had emphasized. They would have to get out of their comfort zone and work hard. Therefore, we had a perfect amount of committed people who really wanted to volunteer for the job ahead. 
Plans were made with all these people to meet at the new building on the next Sabbath. Interestingly, two of those who answered the call on that last Sabbath were not Adventists, but they felt called to come and participate in the mission. After being included in the team and taking part in Bible studies, they were baptized several months later in the new church, where they are very active and committed members now.

I have to admit here that I learned a very important lesson from this "last call” I made on the mother church. I learned that this was not good and therefore I was not going to do it anymore. The general appeal equated all those who came up front to those whom I had trained hard for the new job ahead. Also, I delayed the impetus of those first ones when I had to restrict my time with them in order to teach everything all over again to the new ones.

\section{Second Phase: Planting a New Church}

Now came the time for the second phase: giving birth to a new church one year after having launched the training program. This new church must necessarily always be seen as having a special missional profile. And, following the example of the churches of Colossae and Laodicea (Col 4:16), both churches must have open communication and easy access to each other. This helps keep the balance for both of them, always influencing each other and preserving the principles that gave them reason to be. They belong to each other as parts of the same body accomplishing the same mission.

\section{The New Building}

Since we wanted to reach and include people who do not like going to "church," it was appropriate that the building did not look like one in order to avoid unnecessary prejudices. Therefore, the local conference rented a building and spent more than 
$\mathrm{R} \$ 280,000$ (US\$80,000 in 2015) to prepare it for this purpose. The main room looks like an auditorium with comfortable chairs and two big screens. It is not big, having 180 seats and a large sideways stage that fills one fifth of the space. The building also has nine additional rooms, four of them with glass blackboards, that are used as classrooms during the week for the many courses offered to the community and as Sabbath School classrooms on Sabbath mornings.

The sign outside reads “Espaço Novo Tempo” (New Time Place), which is based on the Adventist channel "TV Novo Tempo" (New Time TV). Thus, it is a name that is not strange to the Adventist public and not too aggressive or "churchy" to the public we want to reach. There are other places with this name in our local Conference, but all of them consist in a small room inside a church, used for Bible classes. ENTC, on the other hand, is a Seventh-day Adventist church itself, focused in reaching people with a postmodern worldview.

First Meetings in the New Building

The first five worship services in the new building were performed behind closed doors, with only the "staff" or "core" members present. It would not be beneficial to invite people other than the core members to a service still being studied and appreciated by these very pioneers. These first five Sabbaths with the core group were spent adapting to the new format, learning how to improve the language, the approach from the stage, the use of music, etc.

In these weeks, the core members and I were able to evaluate our failures and achievements while performing each part as if there were secular visitors present. I could coach them "on the go" even during Sabbath School and the sermon, teaching them what 
to do and what not to do, what to say and what not to say. Thus, we were able to do tests and feel the difference in many details like the worship service language, the relevance of the message itself, and the positive impact they would have on members and visitors.

On one occasion, in a sermon during one of these closed-door meetings, I corrected myself on the spot right after saying the word "colporteur" in an illustration. I told them that our public, on a normal day, would not know what that word meant; therefore, I should rather have said "a person who sells books during his or her vacation in order to earn money to go back to college.” It is longer, but clearer.

During this time, I also met with the core group in the afternoons for observations, lectures, and planning. It was important because every member had to keep in mind that, although we had a different configuration in our Sabbath morning service, we needed to preserve the mission and character of the Seventh-day Adventist Church, never forgetting who we were and our purpose as a prophetic church.

Since many people who came for this mission had not heard the lectures I gave at the previous church, I had to repeat the same ideas, even with the ones who had participated before, in order to reaffirm our vision and future procedures in that place. The content of the sermons and lectures on those five weeks was the following:

1. Ministry of all saints concept

2. Ministries through gifts and skills

3. Culture, tradition and truth

4. The postmodern condition

5. Time, culture, tradition, and evangelism

6. The purpose and mission of the church 
7. Why traditional evangelism methods do not reach postmoderns

8. Paul's strategies depending on his audience's worldview

9. The difference between going to church and being church

10. The necessity of bringing the Gospel to every kindred and tribe

11. Friendship evangelism

12. Engagement to the project

In the second week, a gift test was performed on all core members in order to determine their strongest abilities and match them to specific ministries. Members also had the opportunity to fill out a form specifying all the things they most enjoyed doing in the church. Then we matched everyone with some ministry, task or activity of the church according to their profiles. It was evident they were happy to serve by doing specific activities they could enjoy and were gifted in. They were volunteers doing something pleasant and important for them.

\section{Focus: Urban Evangelism}

The format of the worship is important in such a project, where the intention is to draw urban contemporary secular people to the church. We know the church must create ministries to go where they are instead of just be waiting for them to come to programs in the church. But when they come, the service must be comprehensible to them as well as friendly, relevant, meaningful, and no less powerful than in any church when the Bible is opened.

As proposed by Ellen White (2000), this new church functions as one of many other possible "centers of influence in the large cities.” To reach this goal, the core 
members studied the community during the first six months and planned different ministries. Since the idea was not to work exclusively with postmodern people, but to include them, the members of the church created ministries that might be able to serve the interests and needs of all people in the community.

As we are constantly learning while observing our progress, members are always proposing and creating ministries according to what they would like to do, support, or lead to serve the community. They are always reminded that, in addition to teaching and serving people, all these ministries must have the purpose of making friends, bringing them to our Christian community. We want to disciple people by friendship, leading them to Jesus little by little.

The second church, Espaço Novo Tempo Curitiba (ENTC), offers today many different courses and programs, such as English, photography, guitar, juridical assistance (with a volunteer Seventh-day Adventist lawyer), choir, Pathfinders, youth meeting (even to watch a movie and discuss it against the background of the Great Controversy), vegan fairs, and of course, prayer meeting time and worship time. Today, these ministries keep the church doors open far beyond the worship hours; it is open every day (see appendix).

In addition to the weekly programs, there are many other programs that happen occasionally. There are some Sunday mornings when people are invited by the local radio station to join a motorcycle ride starting from the church building. Some Sundays have a moment for exercise programs led by professionals. Last month we had two great events for the community. One of them was a vegan fair in front of the Espaço Novo Tempo building; it gave us our first contact with many new people. The other one was a course 
on Internet and Social Media Inclusion for the Third Age (as senior people are politely called in Brazil).

It was promoted in partnership with the technology company of the state of Paraná (Celepar). They brought 25 notebook computers and qualified personnel to teach two sections: morning and afternoon. After an intensive week, 32 seniors graduated in a beautiful ceremony at one of our Adventist schools nearby. Three of them are doing Bible studies now. And we have the sympathy of their children and grandchildren, who approved the project and may be open to attending other events in the church.

Other programs will always be developed, as members frequently suggest new activities they would like to perform or participate in. Such activities make the place a real "center of influence," attracting people to be served and people to serve as well. Both groups are interesting, but especially those who come to serve as volunteers. Postmodern people are generally among those who serve, not the ones being served.

\section{Purpose: Transforming Disciples Into Disciple-Makers}

The main purpose of the project in the new building — as it must be in any church-is to have the disciples of Jesus Christ develop a passion for making new disciples. The difference is that the members of the second church learn how to do it in a more contemporaneous way. They know secular people today do not accept people who claim to own the truth. They also know that the new society needs real friendship and transparency, and that these people reject intolerance and prejudice. Thus, members of the second church learn how to get involved with society in a way that helps them be seen as good people who are interested in the good of the community, and who need additional volunteers to do a better job. 
Without being pushy, these trained members know how to get people curious about God, the Bible, and the church. They know how to give Bible studies without following the sequence of the Bible study guides, but according to the need or curiosity of any individual who asks about a specific truth, in the proper time.

Even new members who are baptized in the second church know they need to become fishers of people for the kingdom of God. For this reason, even before being baptized, they also participate in the trainings on how to approach contemporaneous people and make disciples through evangelism by friendship. Thus, before becoming members, they are usually part of a small group or a special ministry. Actually, in a project like this, new members become fishers of men since the beginning, since they normally bring friends to our meetings and invite many relatives and friends to watch their baptisms.

Just minutes after being baptized, when they come to the front of the church to receive their baptism certificate, they also receive some DVDs to watch with friends in a relational small group and a Bible study guide to share with them in the proper time. Since they are new in faith, and therefore may be not ready yet for teaching others, they are encouraged to invite friends to join in the social projects and programs in the church in order to involve them in a bigger net of Christian relationship. In this way, the new members are growing, being nurtured, having communion with the church, and working as disciple-makers, all at the same time.

\section{Special Care for the Seventh-day Adventist Doctrines and Mission}

During those first weeks in the new building, I emphasized again to the core members the difference between traditions/culture and doctrines/principles. I pointed out 
the fact that they were beginning a Seventh-day Adventist church from zero, which meant it did not need to be stuck in formalities or old traditions that we cannot explain beyond the "it was already so when I arrived" formula.

Such traditions include the use of the so-called "platform" (the traditional formation of four or more people seated behind the preacher during the sermon), the requirement of a suit and tie for men and skirt for women to preach or sing, the prohibition of women from wearing trousers in church, etc. The core members understand that these are just cultural and social conventions from a certain period in the past and that they were the best practices for society at that time. They do not make sense any more since they do not break any doctrine or moral law. It is also clear to them that we have to protect the biblical truths as taught by the Seventh-day Adventist Church and live them accordingly.

It was important to make this understanding clear from the beginning because, as expected, as soon as we announced our official opening on local Adventist radio, the church was suddenly overcrowded with Adventist visitors. Many of these visitors probably thought that since we did not use the traditional dress code, we were open to piercings and other things like that as well. Unlike the core group, instead of differentiating between traditions and principles, they apparently see all things together as "rules" until being educated on the difference. My concern was that their very presence, since they were known as baptized and "regular" members, might influence others and give critics the idea that we were really a "liberal church."

For this reason, every two months an "admission meeting" is held for Adventist visitors who want to transfer from their churches to this one. It helps them to understand 
that we are not changing the Seventh-day Adventist Church one bit; that if this church is based on the Bible and on the Spirit of Prophecy, as we believe it is, its doctrines and principles are not to be changed in anything. We are just updating the methods by which the Seventh-day Adventist message is proclaimed to this generation and worldview.

In these meetings, they are informed that, since it is a missional project, those who really want to transfer must be active members, register in a Sabbath School class, join any of the existing ministries or create a new one, and participate in the church for more six months. Then, and only then, will their names be transferred to this church. Many give up in the middle of the process, without which, we would really tend to become only a "liberal” church without the missional and denominational profile.

The core group is constantly reminded in our monthly administrative meetings about our purpose as a missional effort of the Seventh-day Adventist Church, so they will not lose focus on what we are doing there. Otherwise, the thin lines that separate the missional church from the two extremes - an entertainment church or a cold and mechanical traditional one-may soon fade away and disappear, which we do not want to happen at all.

Because of the good music, the informality and probably because of the novelty, the church became too small to accommodate so many believers together, which was not our purpose. I had to ask to the president of my Conference to appeal to all the pastors to tell their parishioners not to go to our church because it was planned to reach nonAdventists; that there is no point in having a missional church overcrowded with people who already know the message leaving no room for the lost! 


\section{Adaptations to Fulfill the Mission}

In order to prevent the new church services from being too different of what we know as the Adventist Church, I decided to keep much of the structure of the traditional church in the worship meetings. The idea is to suggest that much of what we do in the second church can also be done in many existing churches. What should really be different is our approach to secular postmodern people.

Naturally, we meet on Saturday mornings for Sabbath School, which we call “Open Code" —as it is called on the Adventist TV channel in Brazil. After that we have short announcements and then the worship service. We also meet for worship on Wednesday and Sunday nights.

Since the main goal of this project is approaching and including them, the principles of friendship evangelism have been revisited in all church programs and events. I planned with the core group to remodel or improve church events to be more inclusive of this generation. Furthermore, beyond the three worship times that happen in every Seventh-day Adventist church in Brazil during the week, we added the ministries to the church agenda, which keep the church open for many hours every day of the week serving the community. The following sections will discuss how we adapted the worship time and the evangelistic ministries to reach all together the same goal of being an effective missional church for this time.

\section{General Adaptations}

In a project focused on communicating clearly to visitors, obviously the first general adaptation must involve the language used in the church. We avoid phrases and jargon that only Seventh-day Adventist members understand unless it is explained, such 
as "the inspired feather," "the spirit of prophecy," "now let's bend our fronts [to pray]," etc. Although we believe in the things meant by these strange phrases, we must communicate them in an understandable way. Likewise, also the music chosen for all the programs must be understandable to secular people in order to communicate an eloquent message.

Another important general adaptation has to do with the profile of the sermons. They are shorter and to the point, but deeper and meaningful to real $21^{\text {st }}$ century lives. They deal with issues and problems such as relationships, marriage, health, guilt, anxiety, and drugs, always pointing to the hope we have in Jesus and His Word. As we live in a society that is used to watching many things in pixels, short video illustrations are used before and sometimes during the sermons.

Since, at this church, all services are considered evangelistic in nature, sermons are not intended to attack people who do not behave as we do. Therefore, issues such as the use of jewels, tattoos, improper meat, and sexual orientation are not mentioned in the sermons because these are not the kind of messages a first-time visitor would need to hear-especially if he or she is currently living in a situation like that.

However, such issues are obviously studied deeply in our Bible study classes, and those who want to learn more are invited constantly to attend the classes. They will learn such truths there, in the appropriate time—after learning first about the grace and love of God, the authority of His word, the problem of evil, the sacredness of marriage, the notion that our bodies are temples of the Holy Spirit, etc. Evangelistic sermons—as they all are at the second church—are intended to encourage everybody, members and visitors, 
to keep “growing in the grace and knowledge” of Jesus Christ (2 Pet 3:18). People will arrive at all those other points as they keep growing.

Another very important practice that we try to connect to many church programs is sharing meals together at specific moments before or after the meetings. Some churches in Brazil have learned that this strategy is good for church members and for visitors as well. Even sharing light refreshments with worshipers and visitors together creates an opportunity for people to interact and make friends. Any room can be used for this purpose if it is convenient.

Beyond these general adaptations, there are others that are more specific to particular programs, as can be seen below.

\section{Inside the Church}

\section{Sabbath School}

Instead of just "preaching the lesson,” Sabbath School teachers have been trained to lead a good discussion on the issue of the week. Contemporary people like to interact, share their ideas, and contribute to the discussion rather than just listening. In the first Sabbath School weeks, before we received visitors, I gave the Sabbath School teachers lists of questions involving the most important topics from the quarterly lesson in order to generate healthy discussions in the small groups, as well as some hints on how to conduct and conclude the class. I still offer such suggestions every week in case they want some extra ideas.

Depending on the theme of the quarterly lesson, if it seems to be too "aggressive" for an unchurched person, we have a special team and one Sabbath School class reserved for visitors where there will be a different subject from the current quarterly lesson. It is 
located in a separate room in order to show videos on various subjects such as family, health, education, etc. without disturbing the other classes. The plan is to watch the video for about 15 minutes and then have the class discuss the issues and try to apply them to everyone, improving their lives and making them better. But the Bible is always usedas a must-in order to give solid direction and instruction on life issues. If the leaders of this class feel some visitors are ready to learn deeper biblical truths with a cheerful heart, they invite them to the Bible classes available during the week.

We also offer a Sabbath School class in English, which is very helpful in bringing new people to our environment and beginning the process of evangelism by friendship. There is, for example, a young agnostic man who has been coming to our church for four months because of this class. He always stays for the church service after Sabbath School. He pays attention to all parts and even helps with the church website. And best of all, he is our friend.

\section{Sabbath Morning Worship Service}

The Sabbath morning service format does not need to be changed significantly in order to be comprehensible and relevant to postmodern friends. Few things were changed beyond the fact that we do not use the so-called platform during the service and we do not require suit and tie for preaching or singing. In Brazil, this is already a huge and potentially problematic difference. As mentioned before, the most important points are that leaders and church members be naturally receptive, use understandable language in the pulpit (if there is one) and in the songs, preach a meaningful and relevant biblical message, and use more media if possible in order to display illustrations and the lyrics of 
the songs, which must be chosen according to their clarity to unchurched friends. This is the beginning of a friendly church.

\section{A Special Evening Program for Youth and Young Adults}

In order to intentionally include postmodern friends, we hold at Espaço Novo Tempo a special program for young adults that begins at 8 p.m., which is in the evening for the whole year in the south of Brazil. This timing makes it more functional for people who work on Saturdays during the day and then go out at night to have fun in the great urban center of Curitiba. At this time of the evening, unchurched friends could come with them to church and be blessed before going wherever they had planned to go. It runs in seasons of two months each, sometimes on Saturday nights and other times on Sunday nights.

This program is intentionally planned for both evangelism and feeding baptized members. It is more informal, and the speakers wear casual clothes. Since it naturally attracts youth and young adults, it is more interactive, unlike the monologue of a sermon. More videos, music, interviews, discussions, brainstorming, etc., can be used. Such programs are already being accepted at urban churches in Curitiba such as Juvevê Seventh-day Adventist Church, Boqueirão Seventh-day Adventist Church, and Central Curitiba Church.

The leaders of this program are oriented to always finish with an important lesson from the Bible regarding spiritual and practical life, as well as an appeal to adopt a new attitude toward the issue discussed. Among many other themes, these were very interesting to discuss: urban tribes, cultures, technology, human behavior, friendship, marriage, sex, the purpose of life, phobias, death, creation versus evolution, archaeology, 
prophecies, etc. The program happens over three seasons of two months each. In the intervals between the seasons, other kinds of meetings are planned, such as discussions of movies, books, media, and the impact they might have on youth and Christianity. There is also a season in between when we have a youth Bible study class.

\section{Bible Study Classes}

Because the church is trying to be a sensitive church, the Bible study class is an informal discussion, with the lecturer seated among the people in the group, acting as a facilitator of the discussion rather than performing a monologue. During the discussion, the people in the audience (generally only a few) help themselves to healthy beverages or light refreshments. There are four Bible classes during the week: Thursday night, Saturday afternoon, Sunday morning (with the Pathfinders club), and Sunday evening right before the youth worship service, depending on the scheduled season of the year.

\section{Outside the Church}

\section{Small Groups in the Houses}

Adventist small groups in Brazil have a tendency to become home worship services. Many small groups I have visited even used a doxology, very similar to the one used in church. This, of course, is not inviting to unchurched people, and in the end, it becomes one more Adventist meeting without evangelistic results.

Therefore, the members of Espaço Novo Tempo are being trained to transform small groups into pleasant meetings of friends where they can enjoy each other's presence. After some pleasant conversation, the host or the moderator of the group brings 
up a previously selected issue to be briefly discussed by the group with a prayer at the end.

Since this takes some time to planning and we have been creating all the structure of the church, this ministry will be launched next year.

\section{Ministries Serving the Community}

As seen in the previous chapter, postmoderns have the positive desire to help those who are less fortunate and minorities. Therefore, if the church intentionally develops a project for the community, members will be able to invite unchurched friends who are somehow gifted or skilled to help. It is a very good "first contact" for many.

I have noticed that this kind of work brings positive results for all parties involved: it creates a good impression of the church for the community being helped; it brings satisfaction and a sense of purpose to the members who get involved in serving others; and it gives that same satisfaction to non-members who work on the project for the community.

After these friends have helped the community with their skills—as dentists, physicians, etc.- - they are later invited to the church for a "thank you" meeting. At this meeting, the results of the work done are evaluated and appreciated while everyone shares a healthy meal. On this occasion, more projects can be planned for the future, until the day when we have their confidence to invite them to a special program in the church.

These ministries can obviously be adapted and performed in existing churches in order to make them friendlier to postmodern society. But, depending on the church personnel, it may be difficult to go too far beyond these actions. They are performed more freely and have a greater reach in a new church planted intentionally for mission. 


\section{Special (Urban) Ministries}

Here are some special ministries that are making our new Seventh-day Adventist church planted in Curitiba an effective missional church in a contemporaneous world. These ministries were developed based on local members' available skills and geographic opportunities.

\section{Already Functioning}

\section{Adventist Motorcycle Ministry (AMM)}

This is an independent Adventist ministry that has its headquarters in Tampa, Florida, and is spread over nine countries. Despite the fact that it is not an official department of the General Conference of the Seventh-day Adventist Church, the organization recognizes it, since it is led by faithful Seventh-day Adventist members. It reaches many people who would not come to church for conventional worship.

Rides are announced by the local Adventist radio station; people are invited to ride to the beach (70 miles from Curitiba) or to other interesting places. The starting point is the Espaço Novo Tempo building, where we have breakfast and a little prayer before leaving. This is the beginning of contact and friendship. The leaders and members of this ministry meet at the Espaço Novo Tempo Seventh-day Adventist church every other month on a given Friday night for planning and for worship as well.

\section{Walking and Running Ministry}

The leaders of this project always call for non-Adventist professional friends to help in this ministry. They organize walks and runs, announced on local radio and social media, always starting from or arriving at Espaço Novo Tempo. People can enter the 
church to drink water or some other refreshment, and learn about the place through our flyers. The professionals who helped are then invited to a thank-you meeting with a light refreshment, where the event is evaluated and more are planned for the future. The idea is to increase their friendship and confidence. The invitation to come for a worship service will come at the proper time, when we feel it appropriate.

\section{Ministry of Orientation in Creationism}

This ministry made up of graduated members of the church, promotes academic lectures in the church and local colleges, specially trying to impact students at a federal university three miles from our building. This year, in agreement with a professor at the university, this ministry promoted a four-hour lecture performed by an Adventist $\mathrm{PhD}$ in geology. The lecture was about the scientific evidence for a great catastrophe that may support the Bible and the great flood. It was held in the university rectory and attended by more than 110 people, including professors and students.

The class was split into two sections. There was a refreshment in between, which happened in the main hall right in front of the rectory, which helped to get more people curious about the event. At an event like this in such a place, the lecturer was obviously criticized after the speech, with some furious students saying that it was "religion." But several professors and students praised him and thanked him for making them think outside the evolution model in such an academic way. At least three students asked for the address of the place where we meet and gave us their telephone numbers so we could call them to visit us for another discussion like that. The members of this ministry felt they had an experience close to one Paul had in the Areopagus (Atos 17:32-34). They were very excited, both for the event itself and for the three curious students. 
They also held an event with the same theme for the general public in an auditorium for 600 people. All the available seats were reserved for this program (mostly by Adventists), and in the end many people (including many unchurched friends) signed up to learn more about this issue in the future. The ministry is planning another event in order to invite those people again, creating links, increasing friendship and confidence.

\section{Vegan Fair Ministry}

This ministry holds vegan and vegetarian fairs in different parks and places in the neighborhood, inviting people to learn more about the eight natural remedies for the body. Their first experience was very rewarding, since more than 400 people came to the event, which took place in front of our building, with nine booths offering different kinds of vegan food for people to taste and buy. An interesting detail is that only one of the nine fair sellers was Adventist.

There was also a booth with free Adventist books about healthy food designed especially for the general public, and flyers with the schedule of the Espaço Novo Tempo programs. Many people entered the building to watch two scheduled lectures about veganism and healthy cooking. When they asked what the building was for, they learnt it was "a ministry of the Seventh-day Adventist Church to help the community through volunteering and education.”

The ministry crew was satisfied with the results: the eight non-Adventist fair sellers were very impressed by the number of people who came and bought literally everything they had brought to sell. They were invited to a thank-you meeting where we will plan to do it again. Of course, they agreed. In this meeting, we will know each other better while eating vegan food. At least a word of prayer is intended to ask God to bless 
their business. In Brazil, even to nonbelievers, this is well received as a sincere act of sympathy. And we believe it opens the doors of the heart for the Word.

\section{Photography Class}

This ministry is performed once a week in two blocks of three months each by experienced professionals who are members of the local church. They announced that the first module would deal with a specific photographic machine. There came people who had the financial status to own such a machine but did not know how to use all its functions. There are 28 students enrolled in this class right now. This program is just beginning while I write this. The results will be discussed in the next chapter.

\section{English Language Ministry}

As mentioned before, learning English is important for many educated people in Brazil. Two experienced and fluent English speakers volunteered to teach three classes at different levels. After two months of class, we are planning to launch a worship service in English on Saturdays at night and invite the students to come, sing, and improve their listening skills. Friendship must intentionally be well developed during the classes so that students feel comfortable coming to the worship in English when we invite them.

\section{Worship in English}

While the English worship service has the special goal of involving people who are enrolled in the English courses, it naturally will also attract young members and friends in the community who already speak English and those who are striving to learn it or at least love to sing songs in English. As mentioned above, it will be launched about 
two months after the beginning of the English courses, and be held on Saturday nights in a season of six to eight meetings.

\section{Sabbath School in English}

This ministry is simply about handing out the English Sabbath School quarterly lesson to friends who are learning or already speak English so they can study and then practice together on Saturday morning. It is surprising how many people, even agnostics, appear at the Sabbath School class just to practice English.

\section{Ministries Being Planned for the Next Year}

Some of the ministries I learned about at the previous church fit our available skills and local needs as well. We are currently planning to launch these ministries for the next year.

\section{“Exigent Love” Ministry}

As I learned at the previous church, this weekly meeting, held by one or more trained Adventist psychologists, will help parents and relatives of addicted people get strength, support, and direction. At this time, they can share their failures and victories, receive instructions on how to proceed, and make agreements to help each other remain firm while their loved ones are being treated. They also pray for each other.

\section{“How to Stop Getting Fat” Ministry}

Themed on the idea of the traditional (and still effective in poor areas) "How to Quit Smoking,” this program will be performed by an Adventist professional chef. We must adapt our auditorium so that it has all the necessary kitchen equipment and tools for such an event. Then, the attendees will meet every day for a week and then every Sunday 
morning for two months. They will learn not only how to cook healthy food, but also the principles of healthy nutrition and lifestyle. In the beginning all participants will be weighed, and agree to be weighed again together on a specific date to check how much weight they have lost. After that, they will be invited to a special thanksgiving program in the church, where many of them will have their first experience with Seventh-day Adventist worship.

\section{Healthy Cooking Ministry}

This will be the second part of the program "How to Stop Getting Fat," and it will consist of teaching recipes and principles of vegetarian cooking. Many new visitors may begin attending in this second phase of the program and get interested in doing the first part during the next semester.

\section{Skaters' Ministry}

There is a skate ramp in the neighborhood -1 mile from our meeting placewhere dozens of skaters meet regularly to perform their maneuvers. Some young members of our new church are planning to develop a ministry to practice with the other skaters, to become their friends and later on invite them to a special program at Espaço Novo Tempo ("New Time Place” does not sound as scary as "church” for most of them).

According to their plan, leaders of this ministry, together with a team of church leaders, will prepare a special program at our location where the skaters will have lunch and watch some videos or some pictures of their maneuvers and performances on their skates. Then they will be invited to different programs, such as the youth programs, then the worship services, and hopefully the Bible classes. Adventist skaters love to call this an "incarnational ministry." 


\section{Conclusion}

Almost one year after beginning the second church, we are seeing the results of being an inclusive church for all people, instead of an exclusive one for postmoderns only. We have baptized 14 people, including young and old, academic and non-academic people, former Catholics and Protestants, one physician, and two former agnostics as well.

As already suggested, the great adaptation needed in order to reach postmodern and contemporaneous people is not so much in church practices at first, but in ourselves. After we understand the purpose and mission of the church, get love for the lost, understand their worldview, and surrender our will to God, we will indeed become the church for these days, and the Gospel will be more intelligible for the world around us. Then we will stop proving true the Brazilian saying “Adventists go fishing in others' fish ponds,” meaning that we are experts in baptizing people who are already Christians of other denominations as well as nominal Christians. But, if there are limits, a new church must be planted for this mission.

At the end of this project, two years after the beginning of my intervention, I hope to have improved and trained one existing church and planted another one, having both more prepared and equipped to do evangelism in such a way that they bring postmodern people to the church in downtown Curitiba. In the third year, when all the leaders have experience in leading such a church with reliability, I will consolidate the leadership, create a formal committee, and prepare the group to have the official status of an organized church in our local conference. 


\section{CHAPTER 5}

\section{OUTCOMES AND EVALUATION}

This project took three years: the first was spent in an already existing church (Curitiba Central Church) for adaptation and recruiting, and two more years were spent in a newly planted church (Espaco Novo Tempo Curitiba) born out of the first one. In this chapter I present the outcomes, especially those at the second church, which is the main object of this work. These outcomes will also be evaluated against the proposition made in the beginning, which was to create conditions in the church to include and disciple people with the postmodern mind, but without excluding other mindsets.

\section{Outcomes at the First Church}

The outcomes at the first church were relatively small in contrast to its membership of more than 2,600, given several factors. First, this project was supposed to cause much greater impact through the second church than the first one, which already existed when the intervention began.

Second, the personnel and members at the first church did not have the culture of an associate pastor working together with the senior one. Thus, members referred to me as "the evangelist pastor," a role usually performed by a fresh undergraduate pastor who gives Bible study classes in the church and at members' homes.

Third, Curitiba Central Church had already planned their yearly calendar when I arrived, and therefore I had to work within the few gaps in the calendar, as it would not 
be appropriate to create many more events and training programs beyond what they had already set for the year.

However, while visiting people and giving Bible study classes at the church during that year, I had the opportunity to coach many of the ministries that had just been created at the end of the previous year. I was able to instill in them the idea of working in such a way that the postmodern mind might be included somehow, in spite of the fact that it would be very unlikely for postmodern people to go to a "church." Some of them might come, depending on the kinds of programs and services performed for the community outside the church and the approach taken in the church.

I was also able to preach several times to the thousands who watched every Sabbath service both in person and on the Internet. I presented to them the context in which we live now and the necessity of doing contemporaneous evangelism to reach contemporaneous people — our very neighbors, relatives, and friends. Furthermore, many people were recruited for a special training in the second half of the year to be part of the second church, which would be born already prepared for contemporaneous evangelism.

At the end of 2013, the year when I arrived, as a result of the ministry of the three pastors (the church also had a youth pastor) and the dedication of the church leaders through the ministries, and the Bible study classes, many people accepted Jesus as their Savior and became members of the Seventh-day Adventist Church. There was a significant increase in the number of accessions (baptisms, rebaptisms, and professions of faith) over the previous years. Since 2009, this number had been below 100, with the exception of 2011, when a special evangelistic series was performed in the church. In 2013 it reached 100 again, as it did in the following years. 
Table 3

Number of New Members in Curitiba Central Church in the Last Years

\begin{tabular}{|c|c|c|c|c|c|c|c|}
\hline Year & 2009 & 2010 & 2011 & 2012 & 2013 & 2014 & 2015 \\
\hline $\begin{array}{l}\text { Baptisms, } \\
\text { rebaptisms } \\
\text { and } \\
\text { profession } \\
\text { of faith }\end{array}$ & 97 & 75 & 108 & 89 & 100 & 111 & 110 \\
\hline
\end{tabular}

One important outcome that was not measurable in numbers was that the leaders and members of Curitiba Central Church became more acquainted with the reality of the postmodern condition after my coaching. They think more about this condition and all its

implications when they talk about evangelism today and when they plan for the dozens of ministries they have now, as much as possible inside the limits of an established traditional church.

Finally, another important outcome is the new church that was planted. It was based on the strength of the people from Curitiba Central Church who were trained and then volunteered to be pioneers. This new church is making a difference in the community where it is planted now, and teaching other churches how to do evangelism to include contemporaneous people.

\section{Outcomes at the Second Church}

Espaco Novo Tempo Curitiba (ENTC) began with 39 trained members and other volunteers who were trained right after we entered in the new building. It had its first worship service in March 2014, and after some preparation and adjustments it was 
officially launched three months later, in a ceremony attended by the presidents of the local Conference and Union-Conference and many of their respective leaders.

As expected, soon after that, many members of nearby Seventh-day Adventist churches who obviously did not understand the project began to say negative things about ENTC, like "The world came into the church.” Unfortunately, many people consider any worship service "worldly" when it includes drummers and contemporary music instead of music from two or more centuries ago. It is even worse if there is not a formation of four or more people seated behind the preacher, and if the members wear jeans at the meetings. But since the local conference had a vision for the project and believed in it, we had all the support we needed to proceed confidently, and the church kept growing in spite of that issue.

There were also, on the other hand, many Adventists who wanted to be transferred to ENTC. However, it was necessary for each interested person to become active in the church first, becoming a (present) member of the Sabbath school, being involved in any of its ministries, and participating in the acceptance-trainings I would give every three or four months. It was indispensable that the members of the project could understand its reason for existing and the duties of those who are part of it.

At the end of the first year, ENTC had 73 official members, and almost twice that number of people who did not want to meet all the conditions to join, but were content to be "audience" only. At the close of the second year in the new church (2015), while I write these lines, we have 134 members, the great majority of them transferred from other Seventh-day Adventist churches. As shown in Table 4, ENTC members represent all age ranges, evidencing our inclusivity and diversity. 
Table 4

Diversity-inclusivity Showed in the age of the Members of Espaco Novo Tempo Curitiba

\begin{tabular}{ccc}
\hline Age Range & Number of Members & Percentage \\
\hline $\begin{array}{c}12-17 \\
\text { (teens) }\end{array}$ & 7 & $5.2 \%$ \\
$\begin{array}{c}18-35 \\
\text { (young and young-adults) } \\
\text { 36-59 } \\
\text { (adults) } \\
\begin{array}{c}60+ \\
\text { (seniors) }\end{array}\end{array}$ & 74 & $55.2 \%$ \\
\hline TOTAL: & 41 & $30.6 \%$ \\
\hline
\end{tabular}

Source: South Brazilian Union Conference data system (ACMS).

At this church, both the youngsters and the elderly are equally active. One of our three “elders” (using here the church nomenclature), who is especially appreciated by the youth and has a very "youth mind,” is 73 years old. The other two “elders” are respectively 25 and 33 years old, and they all work very well together, sharing ideas and planning evangelism.

This inclusivity and diversity is not only evident in the different ages of members, but also in their varied professions. Among our members, there are physicians, lawyers, administrators, nurses, and nutritionists, as well as plumbers, mechanics, and drivers, all together making plans to serve the other members and reach the secular people. In the area of education, there are many college students and graduate or postgraduate students, as well as people who have had fewer opportunities for formal education.

One interesting observation is the fact that, despite the diversity preached and lived at ENTC, it has naturally attracted mostly people in the range more prone to the postmodern "worldview” in Brazil (young people and college students and graduates). 
Table 5 shows how the proportions are much higher than the average for Seventh-day Adventist churches in the South of Brazil:

Table 5

Comparison to Other Churches in a Spectrum Considered Postmodern Prone in Brazil

\begin{tabular}{ccccc}
\hline & $\begin{array}{c}\text { Espaco } \\
\text { Novo Tempo } \\
\text { (ENTC) }\end{array}$ & $\begin{array}{c}\text { Curitiba } \\
\text { Central Church }\end{array}$ & $\begin{array}{c}\text { Local } \\
\text { Conference } \\
\text { (ASP) }\end{array}$ & $\begin{array}{c}\text { Local Union- } \\
\text { Conference } \\
\text { (USB) }\end{array}$ \\
\hline $\begin{array}{c}\text { Young and } \\
\text { young-adults } \\
(18-35 \text { years-old) }\end{array}$ & $55 \%$ & $30 \%$ & $31 \%$ & $37 \%$ \\
\hline $\begin{array}{c}\text { Undergraduate } \\
\text { and above }\end{array}$ & $41 \%$ & $29 \%$ & $11 \%$ & $9 \%$ \\
\hline
\end{tabular}

Source: South Brazilian Union Conference data system (ACMS).

These numbers show that, proportionally to the number of members, there are many more educated members and young people at ENTC than at the great majority of other Seventh-day Adventist churches in the South of Brazil. When asked what they like about ENTC, they point out the praise (music), the sermons, and their participation. They say that they always learn something new from the Bible that is practical for life, and that they can bring friends because they know the church is prepared for them.

\section{Tithes and Offerings}

The data in figure 2 present an irregular but effective increase in the tithes and the offerings throughout all our experience in the second church until now. Probably because my focus was too much on evangelism, I practically did not include in my trainings with the members or the core members the necessity of being faithful in regards to tithes and offerings. I considered it as “for granted.” As a result, I noticed after the first months that 
the offerings were too disproportional in relation to the tithes. And as soon as December 2014 (nine months after launching the second church), even the tithe numbers were getting below the expected.

After doing a seminar about finances and fidelity in February 2015, I noticed there has been a gradual but significant increase both in the tithes and in the offerings as well, which are no longer being so disproportionate in relation to the tithes. However, after a significant decrease in September 2015, I learnt that this is a topic that really must be remembered and emphasized constantly to keep it working and growing up.

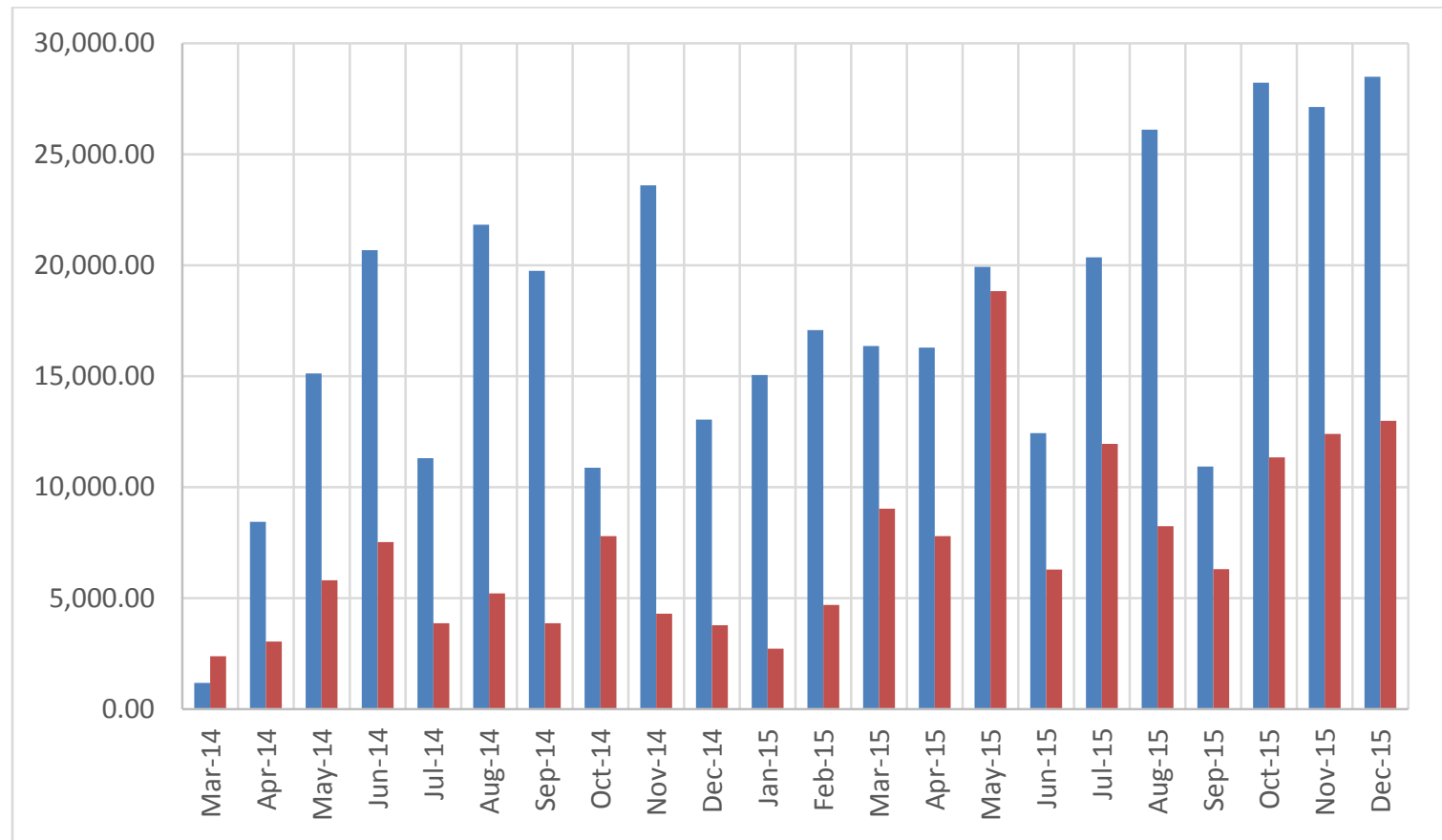

Figure 2. Tithes and offerings in 2014 and 2015 (in Brazilian Currency). Note. Left bars: Tithes; Right bars: Offerings. Source: South Brazilian Union Conference data system (ACMS). 


\section{Accessions Through Baptisms, Rebaptisms, and Professions of Faith}

ENTC also grew through baptisms and professions of faith: 12 people were accepted as members through one of these methods in the first year (2014) and 14 more in the second year (2015), giving a total of 26 accessions in two years.

While these numbers are not so impressive when it comes to baptisms in Brazil, what calls the attention here are the profiles of some of the people who were baptized. They include a physician, a principal of a secondary school, a social worker, college students, a tourism specialist, a former Baptist pastor, and even one former atheist. These are very difficult people to win for the church in Brazil, and it is unusual to see so many of them among such a small number of people entering the same small church.

\section{Diversity in the Accessions}

One important point about ENTC is the idea of inclusion. It is not intended to be an exclusive church for postmoderns only, although they are our focus. ENTC has baptized people who are not young or university students or even “contemporaneous” at all. But all of them were welcomed, understood the message, accepted Jesus as their Savior, and decided to be part of the Seventh-day Adventist family in that place, ministering together with us according to their different abilities and skills.

And as it happened with the Adventist people who were attracted and desired to be transferred to the ENTC, so it was with the people who became new members of the church: most of these people were in the age range and had the educational conditions of those more prone to have a postmodern mindset in Brazil. It means that even ENTC is open to diversity and inclusion, its profile, approach and performance are really being significant for the target-people. 
Table 6

Ages of People Accepted in ENTC Through Baptism or Profession or Faith

\begin{tabular}{ccc}
\hline Age Range & Number & Percentage \\
\hline $12-17$ (teens) & 3 & $11.5 \%$ \\
$18-35$ (young-adults) & 12 & $46 \%$ \\
$36-59$ (adults) & 8 & $30.8 \%$ \\
$60+$ (seniors) & 3 & $11.5 \%$ \\
Total & $\mathbf{2 6}$ & $\mathbf{1 0 0 \%}$ \\
\hline
\end{tabular}

Source: South Brazilian Union Conference data system (ACMS).

\section{Former Adventists}

One interesting fact is that former Adventists appeared in great proportions among the people who were evangelized and decided to become members of the church again. Out of the 26 baptisms, one-third (9) were rebaptisms of ex-Adventists who came back to church.

Table 7

Former Religions of People who Became Members in ENTC

\begin{tabular}{|c|c|c|}
\hline Former Religion & Number & Proportion \\
\hline Protestants & 9 & $34.6 \%$ \\
\hline Catholics & 7 & $27.0 \%$ \\
\hline Adventists & 9 & $34.6 \%$ \\
\hline No Religion/Agnostic & 1 & $3.8 \%$ \\
\hline Total & $\mathbf{2 6}$ & $\mathbf{1 0 0 \%}$ \\
\hline
\end{tabular}

Source: Data collected from members.

\section{Atheists, Agnostics, and No Religion}

It was a great victory for me to baptize one lady who had been an atheist. She had had a great experience in the past when she accepted that there is a God, but she was 
struggling with the idea of belonging to a church. An Adventist friend invited her to our place, and there she not only found the connection between God and the church, but decided to belong to His church as well. Her baptism was a great day for our church members, because several weeks before, with her permission, I had presented to the church some excerpts of her e-mails to me, without her name, showing her struggles to understand the church. She was a real postmodern that we should pray for. They did not know her until the day I announced that the very person we had been studying and praying for was going to be baptized. She is going to Curitiba Central Church now, because it is closer to her house.

There are a few people who declare themselves agnostic who visit ENTC for some special programs, and sometimes attend our worship time on Saturday mornings as well. One lady told me a few months ago that she had been an agnostic until the previous week, when she had gone to our worship service at the insistence of her mother (a former Adventist). I had preached that day about the difference between Horus, Hercules, and Zeus and the God of the Bible, Jehovah. She told me it was everything she needed to know about God: that He is real, historical, and "knowable.” But, unfortunately, we still have a lot to improve. She was so happy with our place that she visited us four Sabbaths in a row, but when she came hand in hand with a girlfriend (yes, "suddenly" she had a homo-affective relationship), something happened and she never appeared again.

While I write these lines (December 2015), there is one unchurched woman who is excited with our Bible studies, saying she is feeling the "vibrations of God" (she is still in the first studies). There is also a young man who says he is an agnostic, but who is voluntarily engaged in the church band and who is now reading the Bible for the first 
time (he says he is finishing Genesis by now). It is really a radical shift. We are open and actively learning to be more prepared to receive many more like them, and to show them Jesus.

\section{Evaluation}

\section{What I Could Have Done Better}

\section{Should Have Established a Church Committee Sooner}

I was concerned about creating a committee that would manage the church appropriately, without the prejudices, practices, and modus operandi of a conventional church in its approach to contemporaneous secular people. But my concern made me take too long to establish this committee, which would have helped me a lot in leading the church without having to make decisions alone.

As a result, I spent too much time planning by myself, training the leaders on what to do and not to do, and trying to present a good job to them. After 18 months in the new church, I finally created the committee with the help of the three elders I had already chosen several months before. I was tired and some of the leaders felt like they were never going to be ready to do the job by themselves or like I was underestimating their capabilities.

Even though I delegated a lot so that leaders could be free to manage their different ministries, I was told by two of them that my leadership was too self-centered without a church committee. They came to give me the "Jethro counsel to Moses.” I explained to them that it was not usual on my part, but I wanted to be sure I was placing the church decisions in the hands of a well-trained committee that would not go back to a conventional church model (in one extreme) or lose focus on the mission of the Seventh- 
day Adventist Church (in another extreme). They understood, and accepted the fact that we were almost there. Today we have such a committee, which is a blessing, but I could have launched it sooner.

\section{Should Have Trained the Choir Members as Much as the Core Members}

Since our choir appeals strongly to the contemporaneous public, many people from other Seventh-day Adventist churches came to participate in it and nothing more. It had a very skilled musician that really attracted the youth. At the beginning, I did not care much when choir members did not come to the trainings and conferences I gave about the purpose and proceedings of the new church. Since their rehearsals happened at the same time as the trainings, sometimes I was just able to share a short devotional with them in the beginning and leave.

But without training these people and giving them the meaning of our church, finally they became "another church" inside the church, without the same focus we cared so much. Now many of them had already transferred to become members of our church, but did not accept much our pleas not to wear piercings and earrings and other things that would create the wrong image of our church and lifestyle.

Close to the end of the second year, we had a conflict about whether we should renew the contract of the musician who led the choir, because of many factors. As it was decided that we would not renew the contract, most of the choir members left our local church together with the musician. We lost 32 choir members, who began to go to other Seventh-day Adventist churches, or to the musician's performances in other places. 
I believe the problem was that most of them had never come to even one administrative meeting of the church or attended the trainings and adaptation processes, and then they did not know what we were there for. They apparently thought that it was a liberal church and I was being authoritative trying to enforce "rules" when that church should finally be their "liberty" from those things. This condition created in part a situation that I had feared before, as mentioned in the previous chapter: more people came to our church thinking it was a liberal church. But unfortunately, they did not give Bible studies, visit, or invite secular friends. They wanted to consume a good show.

I should have planned with the leaders to make it mandatory for choir members to participate in the trainings in order to understand the purpose of the church, and then, if they were accepted, to engage each one of them in our program of discipleship so that they could be part of the choir as members of the church. I know this looks authoritative, but I believe that in order to have a real blessed church, the rule is still valid that it must be done “decently and in order" (1 Cor 14:40).

\section{Should Have Planned Better Strategies to Follow up on Great Events}

The ministries were a blessing for the community: the vegan fair; the healthy activities; the courses in English, photography, and digital inclusion for the "third age" (senior people); etc. But we noticed most people were coming to our programs and not staying for anything else, much less signing up for Bible studies! We know we cannot be too quick to urge contemporaneous people who go to our programs to study religion. But we probably must create a method to improve the continuation of our contact and development of sympathy, friendship and interest. 
We should have created a continuation for the great events. For example, the vegan fair called “Las Vegan” was excellent—we had more than 500 people coming to visit us and buy something—but we should have prepared some flyers with advertising for other programs like vegetarian cooking classes, Pilates ${ }^{1}$ workout or any other activity connected to a healthy lifestyle, and then other programs after those ones like sharing meals together. Finally, there could be a meeting in the church for thanksgiving, which would be the first of a series of studies—-maybe not about religion and the Bible yet, but about family, stress management, administration or anything else, even creating small groups on different subjects.

The same happened with the 600 people who participated in our conference about creation vs. evolution. Many students who came to visit us and get credit for their universities were very impacted by the scientific presentations performed by two Christian scientists. We got a list of all the names and respective ages and religions, but the list was kept "secure" until the "proper time" to call them again. Also in this case, I should have suggested to the members who prepared this event a methodic sequence of other events to give not only more information to this public, but in order to give us opportunities to have more contact and generate friendship. But we learned our lesson and will do better next time.

1 "Pilates" is a physical fitness system originated in the early $20^{\text {th }}$ century, but it boomed in the last decade and is very appreciated in the fitness centers in Brazil. 


\section{Positive Elements}

\section{A Friendlier Church}

The leaders of ENTC understand the necessity of being friendlier to secular visitors. Everything is arranged to make them feel naturally welcome from the beginning; we do not embarrass them by mentioning them from the stage or other exaggerations like that. At the same time, they must feel as soon as possible like they are beloved and they belong. The leaders also understand that the message (from the music and from the pulpit) must be comprehensible to bring light and comfort to visitors, and not use difficult language only for religious people to delight but a fluent message that may bring only hope, assurance, comfort, cure and redirection.

Since this feature has been important in our church, some members have told me they no longer fear inviting friends to church because they know there will not be anything that can scare them or give them a bad impression. They know that every biblical truth presented on the stage will be done with intelligence and reasoning to make a good impression of their faith and improve the lives of their friends.

They understand that the messages from the pulpit are not to attack those who are different, but to show them hope in the light of the Scriptures and in the will of God.

Obviously, all our doctrines must be presented, some of them in special doctrinal programs and all of them in the biblical classes offered during the year.

At ENTC, visitors as well as members are invited to help in some of the ministries that depend on special skills, like healthy fairs, running marathons, informatics, etc. It is a friendly church that is open to serve the community and to receive them well when they come to worship with us-or at least to watch how we do it. 


\section{A Mission-Oriented Church}

All the directors of the departments of ENTC are conscious that the church programs are not intended to entertain or to communicate to believers as an end in themselves. Therefore, they take care that the programs (a) nurture the members in the spiritual life, (b) mobilize them to the mission, and (c) communicate a relevant message to visitors, who must go back to their homes positively impacted.

They also know that more evangelism happens outside the church, through service, than inside, through programs. Therefore, they are always planning strategies to serve the community around the church, in order to create friendship and a good impression of the church for the community. After this is done, there are more chances to invite the community to special programs in the church.

After each speech or preaching, the trained elders and instructed speakers always invite the mixed audience to make a decision in their lives, based on the message just spoken. The visitors who answer the call (together with the members) are always noticed among the people by our selected personnel, and special attention is paid to them afterwards.

The Adventist Motorcycles Ministry (AMM) in Brazil, which is headquartered in our building, has a motto that has become the motto of each department and member of our church when it comes to using our personal skills and hobbies for evangelism: "Do what is necessary in the way that you enjoy.”

\section{A Church That Works for the Community}

As they understand the necessity for postmodern people to participate in social projects, the church is much more engaged in moving outside its walls to serve the 
community. This kind of evangelism is improved when skilled secular friends are invited to help. As a result, such projects involve not only members of the church, but their secular friends as well. The leadership of ENTC is currently making plans to creatively serve the community next year, intentionally looking forward to making friends and then disciples.

\section{A More Interactive Church}

One question that is always present when planning events and programs at ENTC is: how are we going to have people interacting? We want to avoid having people passively listening to a monologue. Thus, we developed a culture of public participation, as much as possible, in our programs. In this way, the talents and skills of people are more appreciated, since members are encouraged to use their gifts and arts to serve God even in the worship meetings. They present skits, poems, and music, and interact or participate more, making the presentations, teachings, and sermons more dynamic and interesting.

Furthermore, after visiting us some times, some of our skilled secular friends are invited to play instruments and sing together with the baptized members in the band or in the choir. This has proven to be a good practice, since three of our new members began as singers or players of instruments before becoming part of our church through Bible studies and baptism.

\section{Conclusion}

I am still learning, and I am sure I will do better work in the future based on the lessons learned from my trials and failures during these three years at Curitiba Central Church and ENTC. As explained before, the idea is not to divide the church into 
exclusive segments for specific groups: the idea is to train the church not only to win postmoderns, but to include them as well. They will come to our meetings when we become more natural and less formal, simpler and less complicated, more committed to principles than forms, and more interested in people than in human traditions; when we love people and hate only sin.

Even though we have baptized some people from difficult demographics for the church to win, we received a lot of criticism from members of other Seventh-day Adventist churches. But, on the other hand, lots of people who visited us understood that many unchurched people and many of their own loved ones will not go to church if it does not improve its approach so they can understand it.

Many have also understood during these years that the Seventh-day Adventist Church is the remnant church of prophecy not because of its 1900s form and practices, but because of its biblical doctrine, which must be preached in such a way that people understand its message today. Traditions and practices may change, but never the word of God and His church's principles. 


\section{CHAPTER 6}

\section{SUMMARY, CONCLUSION, AND RECOMMENDATIONS}

\section{Summary}

The postmodern condition is already a reality in Brazil and is growing fast. People with the postmodern "worldview" are not coming to our church by our conventional evangelistic methods. Church members_-young and old_-are beginning to notice that the current generation is gradually becoming less likely to accept a Bible study or an invitation to go to church. These members need to learn about the postmodern condition and adapt their evangelistic efforts in such a way that people who are experiencing this condition may also be touched by the power of the Gospel.

At the same time, there are some conditions in existing churches that will limit the effectiveness and sometimes even the execution of a project to reach postmodern people: for example, the cold formality of the worship service, the church language, the long introductions and interludes, the traditional music (some of them without meaning for contemporaneous secular people), and too much abstract and apparently irrelevant content brought up by untrained preachers. Depending on the church personnel, some of these practices are very unlikely to change in many churches. Even in a church where leaders want to accomplish the mission, the pastor cannot work beyond the cultural limits imposed by the local members in relation to some practices (such as musical instruments, style of music, sequence of parts in the worship service, etc.). 
Therefore, the solution proposed here is to plant new churches with a vision to perform contemporaneous evangelism. This church must preferably be born out of a mother church that has been trained and adapted within its local/social/cultural limits. Then the mother church must ideally support the second one, understanding that it is a special form of necessary evangelism today. Local members of both churches must be people who are constantly trained to be and to lead such a church, with a vision to bring the Gospel to contemporaneous people in a language they can understand.

However, since postmoderns are less likely to go to church, the second one must be a place that does not look like a conventional church building in Brazil. It must be a center of influence that goes outside of its walls to offer different kinds of service to the community—inviting the very people of the community and circle of friends to help-in order to improve the neighborhood and other people’s lives.

Contemporaneous people who visit the place because of the community projects—either to benefit from them or to serve as voluntary staff—will obviously soon understand the projects are led by religious people, in this case, Seventh-day Adventists. Ideally, they will also learn that these are good people who want to improve other people’s lives outside of the "church.” The great hope is that, after some relationship and friendship, they get curious about the spiritual meetings these people have in that same place—or in their houses—during the week and come to visit when invited (or even before). And when they go, they must love it.

That is what happened in Curitiba, in the Brazilian Southern Union Conference of the Seventh-day Adventist Church. The Central Seventh-day Adventist Church of Curitiba was adapted to the limits of a traditional church, while some of its members 
were recruited and trained to plant a special missional church in the second year-a church that would be born to reach postmodern people.

This second church is called Espaço Novo Tempo Curitiba (this name follows the Adventist TV channel called Novo Tempo, which is broadcast in the city of Curitiba). It is a building with an auditorium, without the appearance of a traditional Brazilian church. It has informal worship services on Saturday mornings and Sunday nights, but it is open every day, featuring courses for the community, such as digital photography, music, English, Digital Inclusion for Seniors, etc. Espaço Novo Tempo has action plans for the neighborhood and hosts events for a healthy lifestyle, such as vegan fairs and walking or running days. It also offers academic events performed by highly qualified people, and recreation events such as those led by the Adventist Motorcycles Ministry.

The evaluation of this project is positive when we observe some characteristics of people baptized in the second church (Espaço Novo Tempo Curitiba) in contrast to traditional churches. Among baptized people, the proportion of youth, college students, graduates, and people in the age range most prone to have a postmodern mindset in Brazil (15-35 years old) is significant in this country. Also, the proportion of youth and college graduates among local members is much higher than the average in the churches of the local conference (ASP) and Union Conference (USB).

The evaluation is also positive when considering the idea of inclusion: it is not an exclusive church for contemporaneous people only, but an inclusive one. Among baptized people and members of the church, there are obviously also people who are below the average for formal education, old people, and very poor people as well. 
One interesting outcome in the evaluation that I did not expect was the great proportion of ex-Adventists who came back to church through this project: almost 50\% of the 26 people baptized in two years.

In regard to the outcome in numbers of baptisms, we must admit that fewer people are baptized in this kind of evangelism and it takes longer to baptize them, in contrast to conventional evangelism. On the other hand, these are people who would not go to a conventional church at first, and they will certainly make a difference in reaching others like them.

After almost two years in the second church, a committee was created to plan and properly decide how to lead that church in order for it to grow and accomplish its mission. Many people who are baptized there then transfer to the Curitiba Central Church or to other churches around to help them keep growing all together as parts of the same body, in the same mission: to make disciples (Matt 28:19).

\section{Conclusion}

As the early church had the challenge of evangelizing the Hellenistic worldwhich had a totally different worldview — the church of today must evangelize contemporaneous people with a postmodern mindset. The early church adapted its methods to communicate the Gospel in a way Hellenistic people would understand, and the church has to do the same today. The first and main adaptation is not so much in the strategies and practices of the church, but in the members' hearts, so that they may love the lost and reach them with love and a clear message.

Based on the fact that many churches cannot adapt their approach very much because of their personnel, the best solution is to inform, recruit, and train people at an 
existing church to plant a new one out of it that will be totally adapted and prepared to receive difficult postmodern people.

Nevertheless, the DNA of the Seventh-day Adventist church, its biblical principles, its very reason to exist, and its God-given mission, cannot "adapt," since they are fundamental and immutable. However, even being the remnant church of the prophecy, proclaiming the three angels' messages to the world (Rev 14:6-12), many current practices of the church in Brazil are only cultural, local, and temporal, and can be adapted to help the church communicate the power of the Gospel without any hindrances or distractions. Only then may unchurched friends finally comprehend the need for Jesus Christ to heal and transform us, and His soon coming to this world as the final solution to resolve all injustice and sin.

In a new church, it will be easier to create new ministries involving many areas of interest of current society (exercises, languages, healthy food and lifestyle, prevention of diseases, family recreation, etc.) that may bring people who need their benefits. This is an effective method of introducing the Gospel today. It is new wine in new wineskins.

\section{Recommendations}

\section{For Pastors and Church Planters}

After three years on this project, I have learned some lessons about “do’s and don'ts” to put into practice when I have to do similar work again. Here are some of those lessons that I want to share with those who would like to plant a Seventh-day Adventist church to include contemporaneous and unchurched people.

The first lesson is that the local conference must support the pastor/church planter. It is very difficult in Brazil to plant a church with the needed characteristics 
without their support. My local conference supported me even to the point of changing the blueprint they had already made for a church they were going to build half a mile from Espaço Novo Tempo Curitiba. In the previous blueprint, the building was a beautiful church temple, like many others of different denominations nearby. I explained to them that this way it would be just “one more church" in our neighborhood. They agreed to change the blueprint, even though they had to pay again for the architect to redraw it. Now it is a beautiful project for an auditorium with many rooms attached. It will be much more attractive for postmodern people to attend, without prejudice.

Furthermore, support from the local conference is very important because there will be lots of criticism coming from sincere people who do not understand "the times" we live in now and therefore do not know "what Israel should do" (1 Chr 12:32). Potential problems will be quenched when these brothers and sisters understand everything is "under control" in our church with the supervision of the leaders "above."

Local church leaders in the first church must also support or at least understand the pastor/church planter. Otherwise, the training and recruiting of members to migrate to the second church will look like stubbornness and rebellion in their eyes. They may not help, or even worse, they could possibly work against the project.

Another recommendation for church planters is to avoid accepting as members of the new church those who do not participate in the trainings. As members of your church and ignoring the purpose of it, they might be a problem because they automatically "represent” your church, which might be good for the critics only.

Always ask for feedback from the core members. They are your right hand. They will be more motivated to work when they can be heard. 
Always read books regarding postmodern reasoning and about the church in postmodern times. Do not forget also to read books about the mission of the Seventh-day Adventist Church and its role in the world as a prophetic church. The Adventist DNA must never be lost of heart and soul.

Never forget to pray and to have people praying for the church planting project, for the people involved, and for you and your family.

\section{For Church Conference Leaders}

I have also learned some important things for conference leaders if they want to help plant churches to reach contemporaneous people.

Do not begin without knowing the demographics of the place. There are neighborhoods in Brazil where the great majority of people do not have the postmodern mindset. The best places are those where people are concentrated in urban centers, wealthy neighborhoods, and close to universities.

Choose pastors who are experienced in the Seventh-day Adventist Church—not only having knowledge of its doctrines, history, principles, and prophetic mission. Many new graduated pastors may not have church experience. Four years in the seminary may be their only "experience” with the church. I believe it is easy for inexperienced young pastors to lose track and transform the new church into something "else."

Support the new church and promote it as a missional effort of the Seventh-day Adventist Church to reach those who would not go to our churches and who need to be saved as well. Members of such a church are real contemporaneous missionaries.

Be patient with the many observations that will come from good members of Seventh-day Adventist churches who do not understand the project. In Brazil, they may 
think the church is in apostasy just because it has a different style of music, dressing, and program.

As much as possible, limit the pastoral district to the mother and new daughter church only. Since many things will be "different of the routine" in these two churches, they will be enough to keep this pastor very busy. It would be very difficult to serve decently a third one, especially if it is too much different of the first two.

Finally, in spite of the fact that in Brazil pastors generally stay about four years in a church district, I would like to suggest to the leaders of a local conference to make plans so that the founding pastor of a new church stay for at least five years. After staying two years in the new planted church and having completed the project, I received a call to another Conference. I believed two years was enough for the trained committee to maintain the church’s progress afterward, but I was wrong. The committee might have been prepared for this, but the members were not. I learned that a new church is identified in great part with the founding pastor, and therefore it is not good that the transition occurs too soon.

\section{The Book of Acts is Still Our Model}

The book of Acts gives us the example of how the early church proceeded when facing the necessity of preaching the Gospel to different people of different mindsets and cultures (e.g., Acts 17). The early church succeeded by planting new churches in many places and adapting to the needs of the local cultures when they did not go against any principle (1 Cor 11:16).

Planting new churches with properly trained people, who love the Lord and His church, who are conscious they have the "everlasting Gospel to preach ... to every 
nation, and kindred, and tongue"- - this is the solution for the church today to accomplish its mission. 


\section{APPENDIX}

FLYER WITH DAILY PROGRAMS FOR THE COMMUNITY
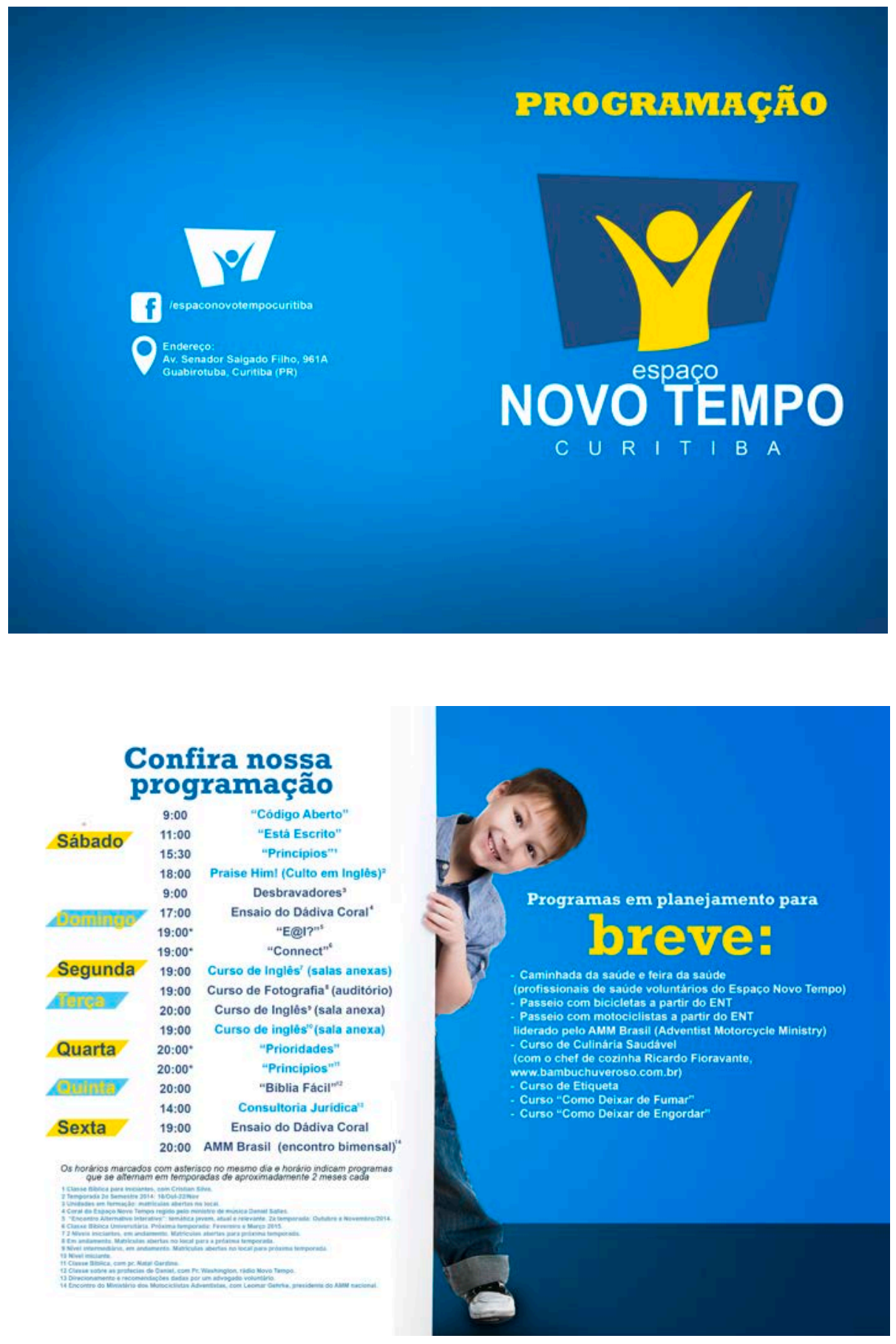


\section{REFERENCE LIST}

Agreste, R. (2007). Igreja? Tô fora! Limeira, SP, Brazil: Editora Socep.

Alexandre, R. (2010, August 9). A nova reforma protestante. Época, 638, 84-92.

Araújo, J. W. C. de. (2009, July). Modernidade e pós-modernidade: Desafios e esperanças para a ética crista. Revista Eclesiástica Brasileira, (69)275. Petrópolis, RJ: Editora Vozes.

Bakke, R. (1987). The urban Christian: Effective ministry in today’s urban world. Downers Grove, IL: Intervarsity Press.

Bast, R. L. (1991). The missing generation: The church's ministry with the Baby Boom. New York, NY: Reformed Church in America.

Bauer, B. L. (2005). Avoiding comfortable syncretism by doing critical contextualization. Journal of Adventist Mission Studies, 1(2), 18-33.

Bauman, Z. (2007). Tempos líquidos. Rio de Janeiro: Jorge Zahar.

Beckham, W.A. (1995). The second reformation: Reshaping the church for the $21^{\text {st }}$ century. Moreno Valley, CA: CCS.

Bock, D. L. (1994). Luke 1:1-9:50. In Baker exegetical commentary on the New Testament. Grand Rapids, MI: Baker.

Borges, M., Reis, D., Assis L. G., \& Cardoso, M. (2012). O resgate da verdade. Tatuí, SP: Casa Publicadora Brasileira.

Bovon, F. (2002). Luke 1:1-9:50. In Hermeneia: A critical and historical commentary on the Bible (Christine M. Thomas, trans.). Minneapolis, MN: Fortress Press.

Bruinsma, R. (2005). Modern versus postmodern Adventism: The ultimate divide? Ministry Magazine, (77)6, 16-21.

Bruinsma, R. (2014). Present truth revisited: An Adventist perspective on postmodernism [Kindle Edition]. Retrieved from www.amazon.com

Bull, M., \& Lockhart, K. (2007). Seeking a sanctuary: Seventh-day Adventism and the American dream. Bloomington, IN: Indiana University Press. 
Burrill, C. (1998). Recovering an Adventist approach to the life and mission of the local church. Fallbrook, CA: Hart Research Center.

Canale, F. (2010). The emerging church: What does it mean? And why should we care? Adventist Review, 187(16), 496-499.

Champlin, R. N. (2002). O Novo Testamento interpretado versículo por versículo (Vol. 4). São Paulo: Hagnos.

Coffin, J. (2010). The emergent church: A practical assessment. Adventist Review, 187(16), 500-502.

Cosgrove, C. H., \& Hatfield, D. D. (1994). Church conflict: The hidden systems behind the fights. Nashville, TN: Abingdon Press.

Cranfield, C. E . B. (1959). The Gospel according to Saint Mark. London, England: Cambridge University Press.

Curar o corpo e a alma. (2012, April). Revista Adventista, 107(1247), 28-29.

Datafolha. (2013). Fatia de Católicos no Brasil é a Menor em Duas Décadas. Retrieved from http://datafolha.folha.uol.com.br/opiniaopublica/2013/07/1314857-fatia-decatolicos-e-a-menor-em-duas-decadas.shtml

Dias, R. (2005). Introdução à sociologia. São Paulo, Brazil: Pearson Prentice Hall.

Donahue, B., \& Robinson, R. (2012). Building a life-changing small group ministry: A strategic guide for leading group life in your church. Grand Rapids, MI: Zondervan.

Dorneles, V. (2006). Cristãos em busca do êxtase: Para compreender a nova liturgia e o papel da música na adoração contemporânea. Engenheiro Coelho, SP, Brazil: Unaspress.

Estudo bíblico para universitários. (2012, April). Revista Adventista, (107)1247, 35.

Friedlander, P. (1973). Plato: An introduction. Princeton, NJ: Princeton University Press.

Gardino, N. (2014). De pós-moderno secular para pós-moderno adventista: compreensão e propostas de estratégias para evangelização. In D. Reis (Ed.), Restauração do papel da revelação cristã na pós-modernidade: Uma perspectiva adventista (pp. 128-146). Ivatuba, Paraná: IAP.

Gladen, S. (2011). Small groups with purpose: How to create healthy communities. Grand Rapids, MI: Baker Books.

Gladden, R. (2000). Plant the future: So many churches! Why plant more? Nampa, ID: Pacific Press. 
Gonçalves, K. O. (2005). A critique of the urban mission of the church in the light of an emerging postmodern condition (Doctoral dissertation). Andrews University, Berrien Springs, MI.

Gonçalves, K. O. (2006). The end of the world as the church used to know it. Journal of Adventist Mission Studies, 2(2), 38-56.

Gonçalves, K. O. (2009). The challenge of the postmodern condition to Adventist mission in South America. Journal of Adventist Mission Studies, 5(1), 4-21.

Gosnell, R. D. (2005). The postmodern paradigm: Challenges to the evangelistic ministry of the church. North Richland Hills, TX: Bibal Press.

Groothuis, D. (2000). Truth decay: Defending Christianity against the challenges of postmodernism. Downers Grove, IL: Intervarsity Press.

Guimarães, A.L. (2010). Cidades e Missão no Antigo Testamento (Doctoral dissertation). Faculdade Teológica Sul-Americana, Londrina, Brazil.

Hahn, T., \& Verhaagen, D. (1998). GenXers after God: Helping a generation pursue Jesus. Grand Rapids, MI: Baker Books.

Hellerman, J. H. (2001). The ancient church as family. Minneapolis, MN: Fortress Press.

Henning, P. C. (2010). A modernidade líquida e o borramento de fronteiras no campo das Ciências. Revista de Estudos Universitários, 36(1). Sorocaba, São Paulo: Universidade de Sorocaba.

Hunter, K. R. (2000). Move your church to action. Nashville, TN: Abingdon Press.

Huttenlocker, K. (1986). Becoming the family of God: A handbook for developing creative relationships in the church. Grand Rapids, MI: Francis Asbury Press.

Kimball, D. (2007). Eles gostam de Jesus, mas não da igreja. São Paulo, Brazil: Editora Vida.

Knight, G. R. (2008). The apocalyptic vision and the neutering of Adventism. Hagerstown, MD: Review and Herald.

Kohler, E. (2012, March). Modernizar sem mundanizar (G. Silva, Interviewer). Revista Adventista, 107(1246), 6-7. Retrieved from http://acervo.revistaadventista.com.br

Lidório, G. J. (2008). Antropologia e Pós-Modernidade. Revista Antropos, 2(1), 59-69.

Lima, W. (2010). Entrevista Kléber Gonçalves: Colheita segmentada. Ministério, 81(1), 5-7.

Lyotard, J. F. (1984). The postmodern condition: A report on knowledge. Minneapolis, MN: University of Minnesota Press. 
Maberly, C. (2005). Contextualization in the context of mainstream 'rock' music listeners. Journal of Adventist Mission Studies, 1(2), 67-82.

Marshall, H. (1992). Luke (Vol. 1). New international Greek Testament commentary. Grand Rapids, MI: Eerdmans.

Mannion, G. (2007). New wine and new wineskins: Laity and a liberative future for the church. International Journal of Practical Theology, 11, 193-211.

McGavran, D. A. (1974). The clash between Christianity and cultures. Washington, DC: Canon Press.

McLaren, B. D. (2000). The church on the other side: Doing ministry in the postmodern matrix. Grand Rapids, MI: Zondervan.

Nichols, F. D. (Ed.). (1957). Acts to Ephesians. Seventh-day Adventist Bible commentary (Vol. 6). Washington, DC: Review and Herald.

Ng, G. T. (2005). Connected to culture, conformed to Christ: Exploring alternate forms of worship. Journal of Adventist Mission Studies, 1(2), 56-66.

Nolland, J. (1989). Luke 1-9:20. In Word biblical commentary (Vol. 35A). Dallas, TX: Word Books.

Norman, E. A. (2007). A strategy for reaching secular people: The intentional church in a post-modern world. Bloomington, IN: AuthorHouse.

Oliveira, E. S. (2003). Orientações básicas para pastores de como implanter e manter pequenos grupos em sua igreja. Salvador, BA, Brazil: Associação Bahia da IASD.

Oliveira, P. (2009). Worldview: Vital for mission and ministry in the $21^{\text {st }}$ century. Journal of Adventist Mission Studies, 5(1), 22-41.

Oliver, B. (2006). Serious about secular society? The challenge of secularism in the twenty-first century. Journal of Adventist Mission Studies, 2(2), 57-67.

Paine, T. (1794). The age of reason. Charlottesville, VI: World Union of Deists. Retrieved from http://www.deism.com/images/theageofreason1794.pdf

Park, J. (2006). The peripheral church of postmodernity. Journal of Adventist Mission Studies, 2(2), 12-24.

Paulien, J. (1993). Present truth in the real world: The Adventist struggle to keep and share faith in a secular society. Boise, ID: Pacific Press.

Paulien, J. (2008). Everlasting gospel ever-changing world: Introducing Jesus to a skeptical generation. Nampa, ID: Pacific Press. 
Pesquisa PUC RS. (2015a). Retrieved from https://www.pucrs.br/blog/pesquisa-ineditaaponta-o-que-o-jovem-pensa-sobre-familia-religiao-e-futuro

Pesquisa PUC RS. (2015b). Retrieved from http://portal.eusoufamecos.net/famecoslanca-estudo-sobre-conceitos-de-familia-2

Pujic, M. (2003). The missionary, $3^{\text {rd }}$ millennium A.D. Nottingham, England: Pyramid Press.

Pujic, M. (2005). A disciple-making strategy to reach the emerging postmodern generation (Doctoral dissertation). Andrews University, Berrien Springs, MI.

Pujic, M. (2006). Postmodernism: An emerging culture. Journal of Adventist Mission Studies, 2(2), 4-11.

Questão de Método. (2012, April). Revista Adventista, 107(1247), 21, 28.

Raschke, C. (2004). The next reformation: Why evangelicals must embrace postmodernity. Downers Grove, IL: Intervarsity Press.

Reader, J. (1997). Beyond all reason: The limits of post-modern theology. Great Britain: Aureus.

Robbins, V. K. (1982, April). Mark 1:14-20: An interpretation at the intersection of Jewish and Graeco-Roman traditions. New Testament Studies, 28(2).

Rode, I., \& Rode, D. (2007). Crescimento: Chaves para revolucionar sua igreja. Engenheiro Coelho, SP: Unaspress.

Sahlin, M., \& Richardson, P. (2008, November). Seventh-day Adventists in North America: A demographic profile. North American Division secretariat demographic survey. Milton Freewater, OR: North American Division and the Center for Creative Ministry.

Schieber, A. L., \& Olson, A. T. (Eds.). (1999). What next? Connecting your ministry with the generation formerly know as $X$. Minneapolis, MN: Augsburg Fortress.

Smith, R. S. (2005). Truth and the new kind of Christian: The emerging effects of postmodernism in the church. Wheaton, IL: Crossway Books.

Stein, G. (2012). Do Brasil para o mundo. Revista Adventista, 107(1245), 37.

Stetzer, E. (2015). Plantando Igrejas Missionais: Como Plantar Igrejas Bíblicas, Saudáveis e Relevantes à Cultura. São Paulo, Brasil: Editora Vida Nova.

Tavares, D. (2009). Developing a relational-based evangelism training program to equip church leaders and members in the north Brazil Union (Doctoral dissertation). Berrien Springs, MI: Andrews University. 
Thornton, J. (2006). Postmodernity: Challenge and opportunity. Journal of Adventist Mission Studies, 2(2), 25-37.

Veith, G. E. (1994). Postmodern times: A Christian guide to contemporary thought and culture. Wheaton, IL: Crossway Books.

Wallace, D. B. (1996). Greek grammar beyond the basics: An exegetical syntax of the New Testament. Grand Rapids, MI: Zondervan.

White, E. G. (1943). Counsels to parents, teachers and students regarding Christian education. Mountain View, CA: Pacific Press.

White, E. G. (1952). Welfare ministry: Instruction in Christian neighborhood service. Washington, DC: Review and Herald.

White, E. G. (2002). Evangelism. Hagerstown, MD: Review and Herald.

White, E. G. (2003). The ministry of healing. Nampa, ID: Pacific Press.

White, E. G. (2008). Sketches from the life of Paul. Hagerstown, MD: Review and Herald.

White, E. G. (2009). Christian service. Lexington, KY: Feather Trail Press.

White, E. G. (2010). Prophets and kings. Nampa, ID: Pacific Press.

White, H. (2006). Postmodernism 101: A First course for the curious Christian. Grand Rapids, MI: Brazos Press.

Wuellner, W. H. (1967). The meaning of 'fishers of men.' Philadelphia, PA: The Westminster Press.

Zoba, W. M. (1999). Generation 2k: What parents and others need to know about the millennials. Downers Grove, IL: InterVarsity Press. 


\section{VITA}

Name: Natal Gardino

Date of Birth: December 24, 1971

Place of Birth: São Paulo, SP - Brazil

Spouse: Irineide de Carvalho Gardino

Children: Kaléo (2006) and Nicholas (2009)

\section{Education:}

2011-2016 DMin in Leadership, Andrews University.

2009-2011 M.A. from Seventh-day Adventist Theological Seminary, Andrews University Seminary. Emphasis on New Testament.

1999-2002 Bachelor of Arts in Theology/Pastoral and Educational Emphasis from UnaspEC Centro Universitário Adventista, campus Engenheiro Coelho.

\section{Ordination:}

2006 Ordained to the Seventh-day Adventist Gospel Ministry

\section{Experience:}

2016-Present District Pastor of Jardim Iguaçu Seventh-day Adventist Churches, Maringá (PR), Brazil.

2014-2015 Pastor of Espaço Novo Tempo Curitiba (PR), Brazil.

2013 Associate Pastor of Curitiba Central Seventh-day Adventist Church, Curitiba (PR), Brazil.

2009-2009 Part time pastor ministering to Fall River Portuguese Seventh-day Adventist Church, (MA), USA.

2006-2007 District Pastor of Gravataí (RS), Brazil.

2003-2005 District Pastor of Alto Maracanã, Colombo (PR), Brazil.

2003 Teacher of Religion at the Colégio Adventista Boa Vista, Curitiba (PR), Brazil. 
